\title{
U.S. Geological Survey Energy and Minerals Science Strategy-A Resource Lifecycle Approach
}

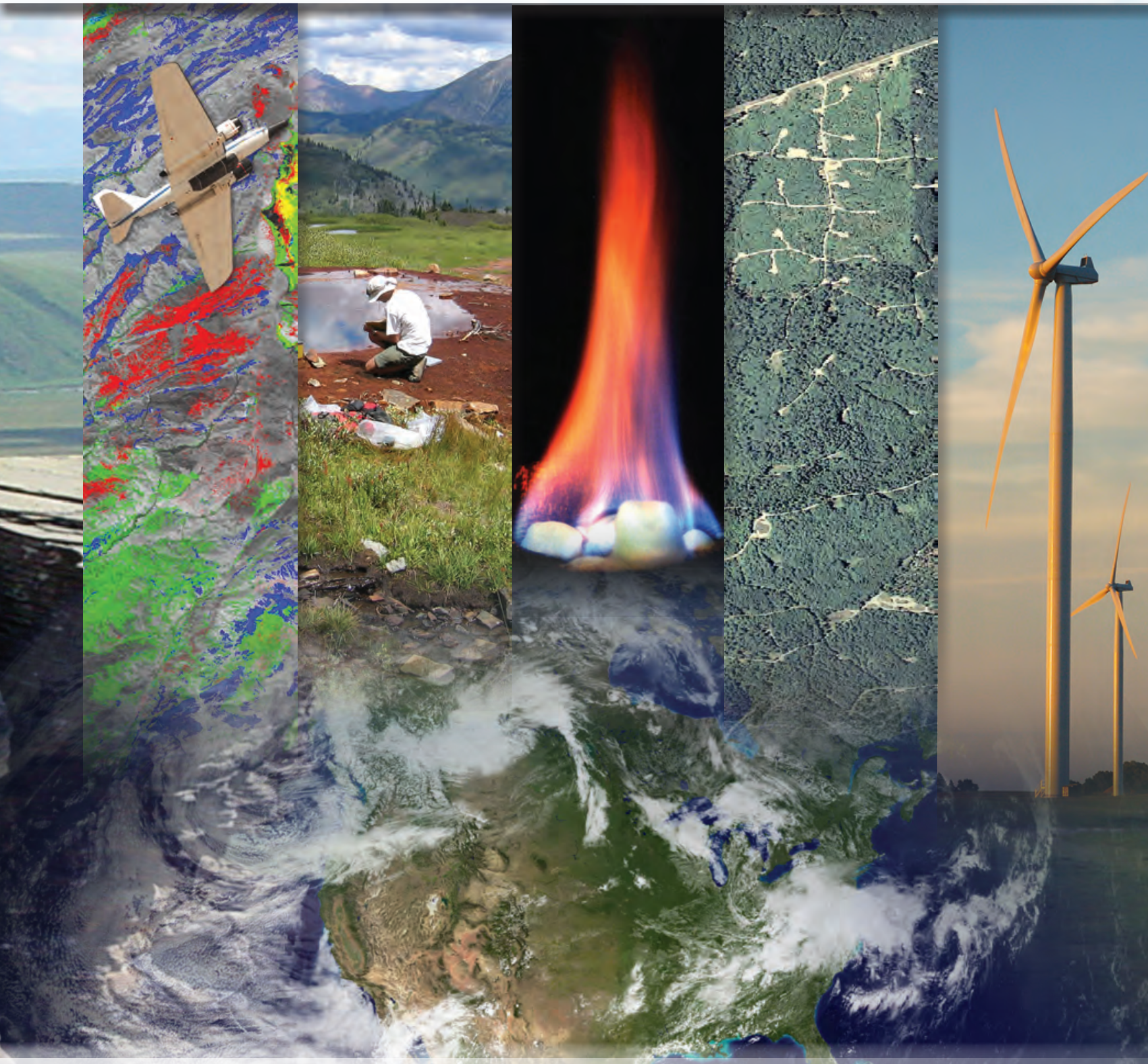

Circular 1383-D

U.S. Department of the Interior U.S. Geological Survey 


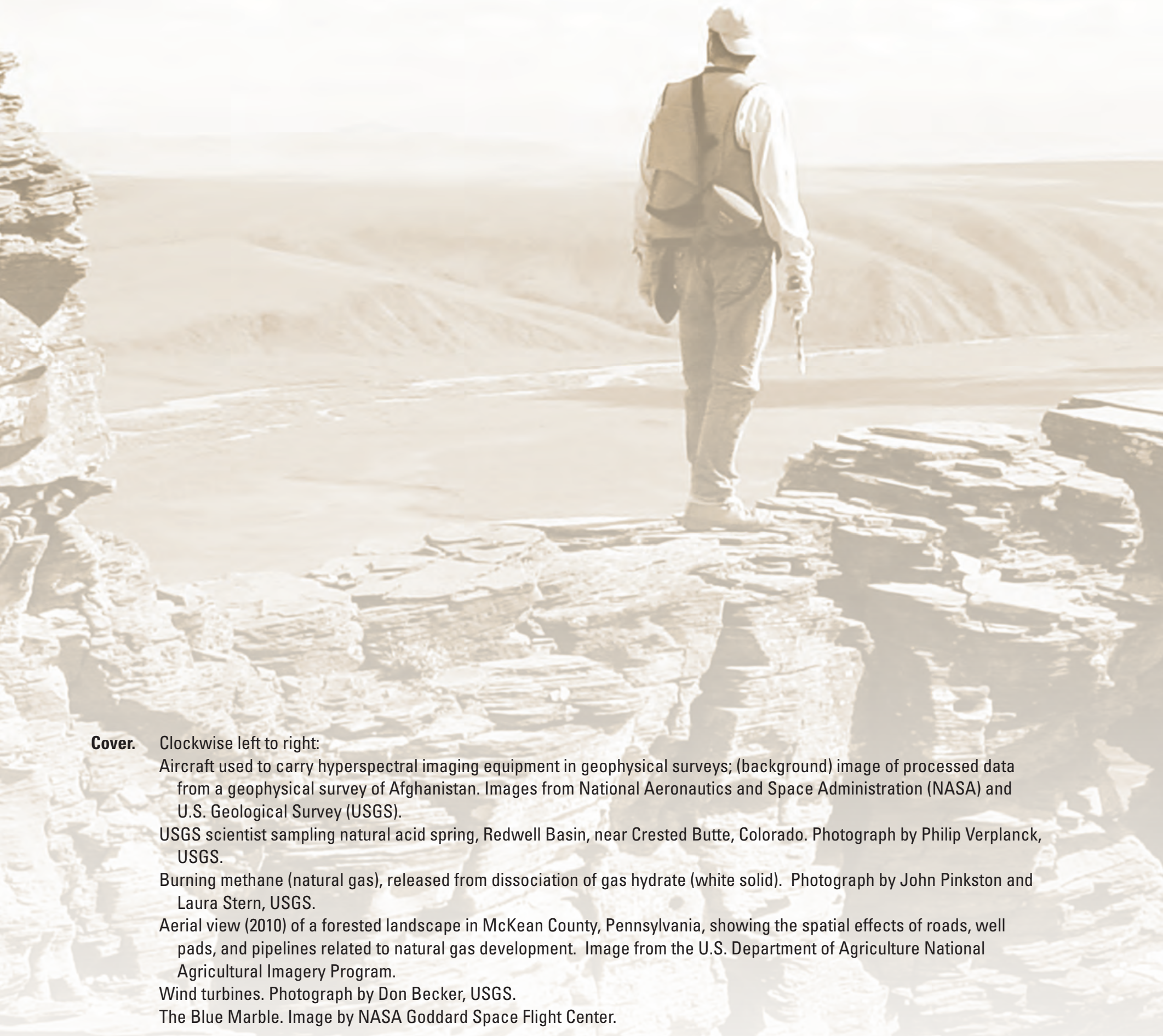

Background. Geologist on outcrop of Nanushuk Formation, Tuktu Bluff, Alaska. Photograph by Dave Houseknecht, USGS. 


\section{U.S. Geological Survey Energy and Minerals Science Strategy-A Resource Lifecycle Approach}

By Richard C. Ferrero, Jonathan J. Kolak, Donald J. Bills, Zachary H. Bowen, Daniel J. Cordier, Tanya J. Gallegos, James R. Hein, Karen D. Kelley,

Philip H. Nelson, Vito F. Nuccio, Jeanine M. Schmidt, and Robert R. Seal 


\section{U.S. Department of the Interior \\ KEN SALAZAR, Secretary \\ U.S. Geological Survey \\ Marcia K. McNutt, Director}

U.S. Geological Survey, Reston, Virginia: 2013

For more information on the USGS - the Federal source for science about the Earth, its natural and living resources, natural hazards, and the environment, visit http://www.usgs.gov or call 1-888-ASK-USGS.

For an overview of USGS information products, including maps, imagery, and publications, visit http://www.usgs.gov/pubprod

To order this and other USGS information products, visit http://store.usgs.gov

Any use of trade, firm, or product names is for descriptive purposes only and does not imply endorsement by the U.S. Government.

Although this information product, for the most part, is in the public domain, it also may contain copyrighted materials as noted in the text. Permission to reproduce copyrighted items must be secured from the copyright owner.

Suggested citation:

Ferrero, R.C., Kolak, J.J., Bills, D.J., Bowen, Z.H., Cordier, D.J., Gallegos, T.J., Hein, J.R., Kelley, K.D., Nelson, P.H., Nuccio, V.F., Schmidt, J.M., and Seal, R.R., 2013, U.S. Geological Survey energy and minerals science strategyA resource lifecycle approach: U.S. Geological Survey Circular 1383-D, 37 p. 


\section{Foreword}

In 2007, the U.S. Geological Survey (USGS) published a Bureau Science Strategy Facing Tomorrow's Challenges - U.S. Geological Survey Science in the Decade 2007-2017. It provided a view of the future, establishing science goals that reflected the USGS's fundamental mission in areas of societal impact such as energy and minerals, climate and land use change, ecosystems, natural hazards, environmental health, and water. Intended to inform long-term program planning, the strategy emphasizes how USGS science can make substantial contributions to the well-being of the Nation and the world.

In 2010, I realigned the USGS management and budget structure, changing it from a structure associated with scientific disciplines — Geography, Geology, Biology and Hydrology — to an issue-based organization along the lines of the Science Strategy. My aim was to align our management structure with our mission, our science priorities, our metrics for success, and our budget. An added benefit was that the USGS immediately appeared relevant to more Americans, and it became easier for those outside the agency to navigate our organizational structure to find where within the USGS they would find the solution to their problem. External partners rarely approached us with a problem in "geology," but they might need help with an issue in climate change or energy research.

The new organization is focused on seven science mission areas:

- Climate and Land Use Change

- Core Science Systems

- Ecosystems

- Energy and Minerals

- Environmental Health

- Natural Hazards

- Water

The scope of each of these new mission areas is broader than the science directions outlined in the USGS Science Strategy and together cover the scope of USGS science activities.

In 2010, I also commissioned seven Science Strategy Planning Teams (SSPTs) to draft science strategies for each USGS mission area. Although the existing Bureau Science Strategy could be a starting point for this exercise, the SSPTs had to go well beyond the scope of the existing document. What is of value and enduring from the work of the programs that existed under the former science disciplines needed to be reframed and reinterpreted under the new organization of the science mission areas. In addition, new opportunities for research directions have emerged in the five years since the Bureau Science Strategy was drafted, and exciting possibilities for cooperating and collaborating in new ways are enabled by the new mission focus of the organization.

Scientists from across the Bureau were selected for these SSPTs for their experience in strategic planning, broad range of experience and expertise, and knowledge of stakeholder needs and relationships. Each SSPT was charged with developing a long-term (10-year) science strategy that encompasses the portfolio of USGS science in the respective mission area. Each science strategy will reinforce others because scientific knowledge inherently has significance to multiple issues. Leadership of the USGS and the Department of the Interior will use the science vision and priorities developed in these strategies for program guidance, implementation planning, accountability reporting, and resource allocation. These strategies will guide science and technology investment and workforce and human capital strategies. They will inform our partners regarding opportunities for communication, collaboration, and coordination.

The USGS has taken a significant step toward demonstrating that we are ready to collaborate on the most pressing natural science issues of our day and the future. I believe a leadership aligned to support these issue-based science directions and equipped with the guidance provided in these new science strategies in the capable hands of our scientists will create a new era for USGS of which we can all be proud.

Marcia McNutt

Director 


\section{Mission and Vision}

The U.S. Geological Survey energy and minerals mission is to provide impartial science and information for understanding the occurrence and distribution of national and global energy and mineral resources that may contribute to supplies; the potential environmental and socioeconomic effects associated with resource occurrence and use; and the global supply and flow of nonfuel mineral commodities.

Over the coming decade, science leading to a broader understanding of the resource lifecycle will be a cornerstone for decisions supporting our Nation's economic vitality, protection of natural resources, security of resource supplies, and quality of life.

\section{Acknowledgments}

We thank the USGS employees, Federal, State, and tribal partners, and members of the public who provided input throughout the strategic planning process. We are grateful to Maeve Boland for her assistance and candor during the development of this strategy.

We also thank USGS employees Jim Coleman, Marty Goldhaber, Yousif Kharaka, Keith Long, Chris Schenk, and Mark Sogge for their thoughtful peer reviews that improved this science strategy. 


\section{Contents}

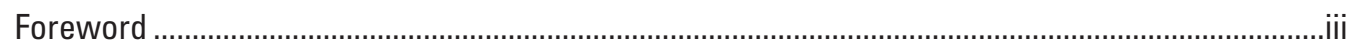

Mission and Vision.................................................................................................................

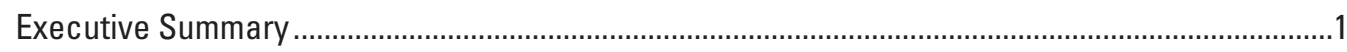

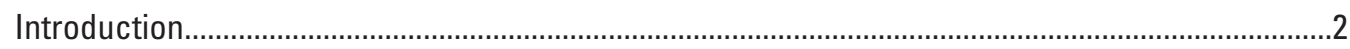

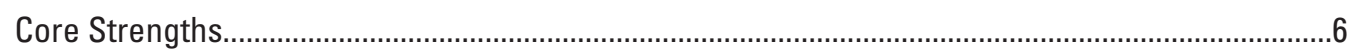

Mandates and Authorizations ................................................................................................

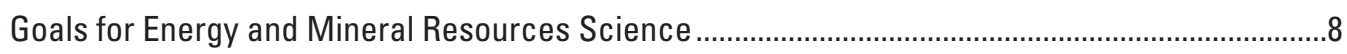

Goal 1: Understand Fundamental Earth Processes that Form Energy and

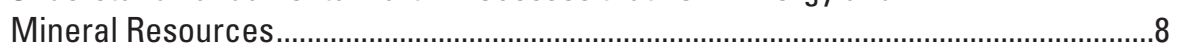

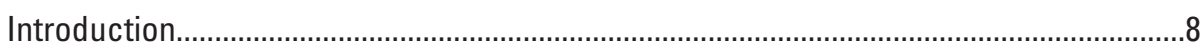

1-1. Geologic and Tectonic Framework Studies .......................................................

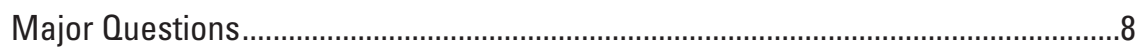

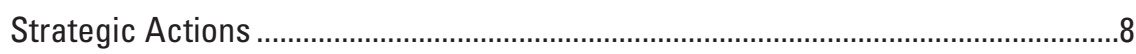

1-2. Evolution of Energy and Mineral Systems......................................................... 10

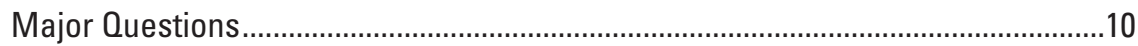

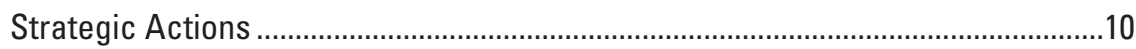

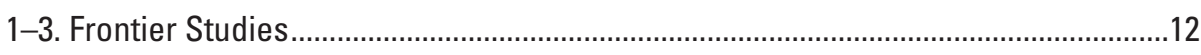

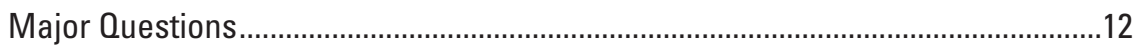

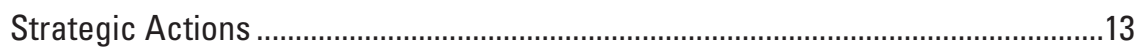

Goal 2: Understand the Environmental Behavior of Energy and Mineral Resources and Their Waste Products ..........................................................................................

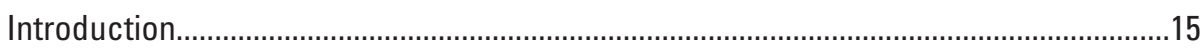

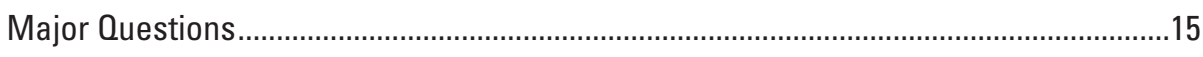

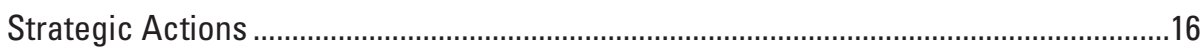

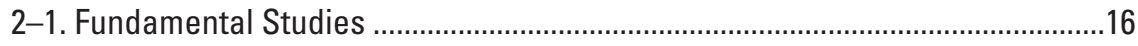

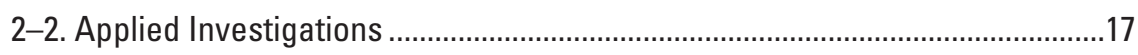

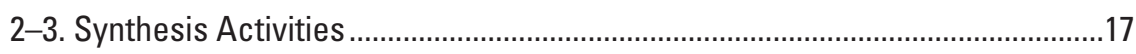

Goal 3: Provide Inventories and Assessments of Energy and Mineral Resources .................18

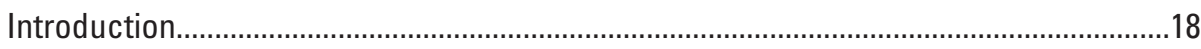

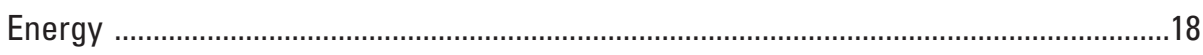

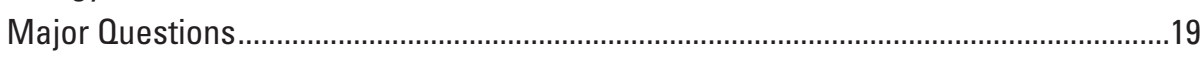

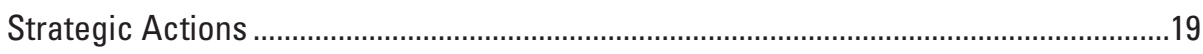

3-1. Undiscovered Geologically Based Energy Resources....................................19

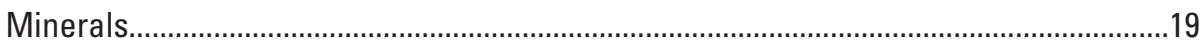

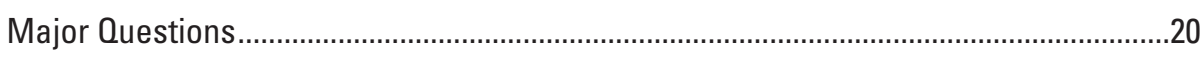

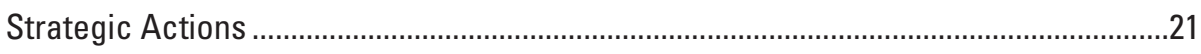

3-2. Discovered Nonfuel Mineral Resources ......................................................21

3-3. Undiscovered Nonfuel Mineral Resources........................................................21 
Goal 4: Understand the Effects of Energy and Mineral Development on Natural

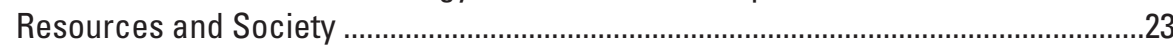

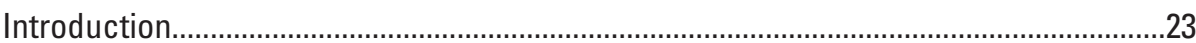

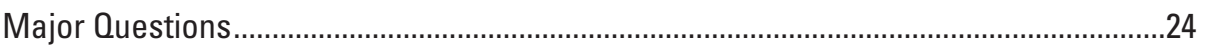

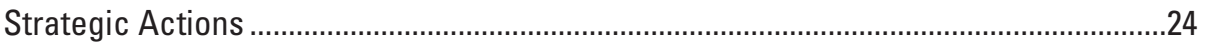

4-1. Spatial Analysis of Energy and Mineral Resources Occurrence and Development

4-2. Exploring Interdisciplinary Approaches for Assessing Effects of Energy and Mineral Development.

Goal 5: Understand the Reliability and Availability of Energy and Mineral Supplies ..............27

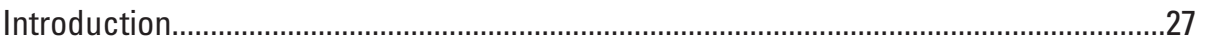

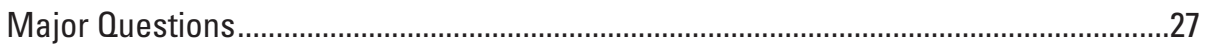

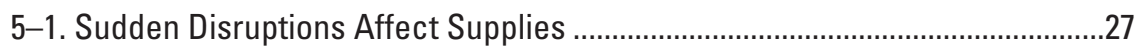

5-2. Evolving Issues Affect Long-Term Availability....................................................

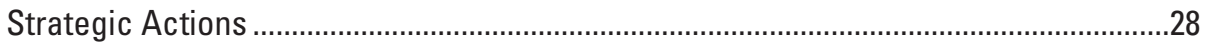

5-1. Sudden Disruptions Affect Supplies .............................................................28

5-2. Evolving Issues Affect Long-Term Resource Availability ................................28

Energy and Minerals Linkages Within the U.S. Geological Survey...................................................

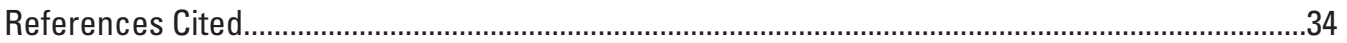

\section{Figures}

1. Diagram and map showing the magnitude and distribution of mineral resource production activities across the Nation.

2. Map showing areas of historical oil and gas exploration and production in the conterminous United States through 2006

3. Conceptual diagram that depicts a resource lifecycle for energy and minerals ..............4

4. Geologic model output showing a south-to-north cross section at present day, and 300 million years ago, and a 3-D model of thermal maturation using Woodford Shale transformation ratio

5. Isoresource map of Mahogany oil shale zone in Uinta and Piceance Basins showing oil yield in gallons per ton

6. Map showing the U.S. Exclusive Economic Zone and photographs showing nodules

7. Photograph showing solar panels installed at the Denver Federal Center in Lakewood, Colorado

8. Matrix showing where the U.S. Geological Survey provides assessment and information for energy resources, and mineral resources by geographic region and resource category 
9. Map showing the extent of the Marcellus assessment units within the Appalachian Basin geologic province

10. Photographs of the Lemhi Pass thorium district in Idaho and Montana .........................22

11. Photograph showing the Kanab North Mine, one of several breccia-pipe uranium mines in northern Arizona

12. Conceptual diagram for an integrated assessment .......................................................25

13. Screen capture showing the Wyoming Landscape Conservation Initiative integrated assessment Web interface

14. Map showing the locations of mines and mineral facilities in Japan

15. Diagrams showing materials flow models

\section{Tables}

1. Summary of goals and actions for the U.S. Geological Survey energy and minerals science strategy.

2. Principal mandates and authorizations related to U.S. Geological Survey energy and minerals activities and their intersection with each of the five goals in the energy and minerals science strategy.

3. U.S. Geological Survey energy and minerals science strategy actions and intersections with other mission areas..

\section{Highlights}

The Advantages of Three-Dimensional Models and Visualization. 9

Oil Shale: Evaluating an Energy Resource and Its Extractive Effects................................. 11

Minerals in the U.S. Exclusive Economic Zone .............................................................. 14

Renewable Energy and Nonrenewable Mineral Resources ............................................ 16

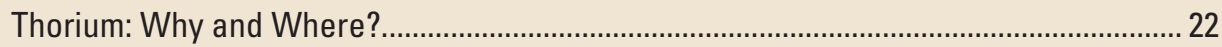

Uranium in the Grand Canyon: A Case Study in Integrated Research and

Assessment... .25

Integrated Assessment for Southwestern Wyoming................................................... 26

USGS Scientific Contributions to Disaster Response Following the 2011 Japan

Earthquake and Tsunami

Materials Flow Analysis: Illustrating Global Commodity Supply Vulnerabilities. 
viii

\section{Conversion Factors}

Inch/Pound to SI

\begin{tabular}{|c|c|c|}
\hline Multiply & By & To obtain \\
\hline \multicolumn{3}{|c|}{ Length } \\
\hline inch (in.) & 2.54 & centimeter $(\mathrm{cm})$ \\
\hline foot $(\mathrm{ft})$ & 0.3048 & meter $(\mathrm{m})$ \\
\hline mile (mi) & 1.609 & kilometer (km) \\
\hline mile, nautical (nmi) & 1.852 & kilometer $(\mathrm{km})$ \\
\hline \multicolumn{3}{|c|}{ Area } \\
\hline acre & & square meter $\left(\mathrm{m}^{2}\right)$ \\
\hline acre & 0.4047 & hectare (ha) \\
\hline acre & 0.004047 & square kilometer $\left(\mathrm{km}^{2}\right)$ \\
\hline square mile $\left(\mathrm{mi}^{2}\right)$ & 2.590 & square kilometer $\left(\mathrm{km}^{2}\right)$ \\
\hline \multicolumn{3}{|c|}{ Volume } \\
\hline barrel (bbl), (petroleum, 1 barrel=42 gal) & 0.1590 & cubic meter $\left(\mathrm{m}^{3}\right)$ \\
\hline gallon (gal) & 3.785 & liter $(\mathrm{L})$ \\
\hline gallon (gal) & 0.003785 & cubic meter $\left(\mathrm{m}^{3}\right)$ \\
\hline cubic foot $\left(\mathrm{ft}^{3}\right)$ & 0.02832 & cubic meter $\left(\mathrm{m}^{3}\right)$ \\
\hline \multicolumn{3}{|c|}{ Mass } \\
\hline pound, avoirdupois (lb) & 0.4536 & kilogram (kg) \\
\hline ton, short $(2,000 \mathrm{lb})$ & 0.9072 & metric ton $(\mathrm{t})$ \\
\hline ton, long $(2,240 \mathrm{lb})$ & 1.016 & metric ton $(\mathrm{t})$ \\
\hline
\end{tabular}

Temperature in degrees Celsius $\left({ }^{\circ} \mathrm{C}\right)$ may be converted to degrees Fahrenheit $\left({ }^{\circ} \mathrm{F}\right)$ as follows:

${ }^{\circ} \mathrm{F}=\left(1.8 \mathrm{x}^{\circ} \mathrm{C}\right)+32$

Temperature in degrees Fahrenheit $\left({ }^{\circ} \mathrm{F}\right)$ may be converted to degrees Celsius $\left({ }^{\circ} \mathrm{C}\right)$ as follows:

${ }^{\circ} \mathrm{C}=\left({ }^{\circ} \mathrm{F}-32\right) / 1.8$ 


\section{Abbreviations}

3

three-dimensional

4D four-dimensional

AU assessment unit

BLM Bureau of Land Management

BOEM Bureau of Ocean Energy Management

$\mathrm{CO}_{2}$ carbon dioxide

DOE Department of Energy

DOI Department of the Interior

ECS extended continental shelf

EEZ exclusive economic zone

EIA Energy Information Administration

EPA Environmental Protection Agency

Ma millions of years ago

MOU memorandum of understanding

MRDS Mineral Resources Data System

Mt million metric tons

NMIC National Minerals Information Center

PGM platinum-group metal

PL Public Law

REE rare earth element

SI Système International d'Unités (International System of Units)

SSPT Science Strategy Planning Team

UNCLOS United Nations Convention on the Law of the Sea

USC U.S. Code

USGS U.S. Geological Survey

WLCl Wyoming Landscape Conservation Initiative

WTC World Trade Center 



\title{
U.S. Geological Survey Energy and Minerals Science Strategy-A Resource Lifecycle Approach
}

\author{
By Richard C. Ferrero, Jonathan J. Kolak, Donald J. Bills, Zachary H. Bowen, Daniel J. Cordier, \\ Tanya J. Gallegos, James R. Hein, Karen D. Kelley, Philip H. Nelson, Vito F. Nuccio, Jeanine M. Schmidt, \\ and Robert R. Seal
}

\section{Executive Summary}

The economy, national security, and standard of living of the United States depend heavily on adequate and reliable supplies of energy and mineral resources. Based on population and consumption trends, the Nation's use of energy and minerals can be expected to grow, driving the demand for ever broader scientific understanding of resource formation, location, and availability. In addition, the increasing importance of environmental stewardship, human health, and sustainable growth places further emphasis on energy and mineral resources research and understanding. Collectively, these trends in resource demand and the interconnectedness among resources will lead to new challenges and, in turn, require cutting-edge science for the next generation of societal decisions.

The long and continuing history of U.S. Geological Survey contributions to energy and mineral resources science provide a solid foundation of core capabilities upon which new research directions can grow. This science strategy provides a framework for the coming decade that capitalizes on the growth of core capabilities and leverages their application toward new or emerging challenges in energy and mineral resources research, as reflected in five interrelated goals.

Twin Groves wind farm in McLean County, Illinois. Photograph by Guenter Conzelmann, Argonne National Laboratories.
- Goal 1.-Understand fundamental Earth processes that form energy and mineral resources

- Goal 2.-Understand the environmental behavior of energy and mineral resources and their waste products

- Goal 3.-Provide inventories and assessments of energy and mineral resources

- Goal 4.- -Understand the effects of energy and mineral development on natural resources and society

- Goal 5.-Understand the reliability and availability of energy and mineral supplies

Within each goal, multiple actions are identified. The level of specificity and complexity of these actions varies, consistent with the reality that even a modest refocus can yield large payoffs in the near term whereas more ambitious plans may take years to reach fruition. As such, implementation of these actions is largely dependent on available resources and the sequencing of prerequisite steps. This science strategy places an emphasis on interdisciplinary collaboration and leveraging of expertise across the U.S. Geological Survey and with external partners. 


\section{Introduction}

Energy and mineral resources are essential to society. The U.S. Geological Survey (USGS), as the Nation's principal natural science bureau, advances the science of energy and mineral resources and provides statistical information and analysis on the global flow of minerals and mineral materials. The Organic Act of 1879 defines the role of the USGS as "... the classification of the public lands and examination of the geological structure, mineral resources, and products of the national domain." Understanding the science, quality, quantity, and spatial distribution of energy and mineral resources has been a core function of the USGS since its inception. The USGS is recognized by industry, nongovernmental organizations, and international, Federal, State, tribal, and local governments for its reliable, high-quality energy and minerals science, information, fundamental research, and expertise.

This science strategy, intended to reach multiple audiences, describes the USGS role and suggests actions that can be taken in the next 10 years to provide the Nation with high-impact energy and minerals science and information on recognized and emerging issues. The goals represent broad directions; the actions represent specific research thrusts to advance these goals. Collectively, the understanding gained from these actions provides information for decisionmaking with respect to such issues as economic vitality, environmental health, national security, and responsible resource management and protection on U.S. Department of the Interior (DOI) and other lands.

The United States uses substantial amounts of energy and mineral resources each year. In 2011, industries that consumed processed mineral materials added about $\$ 2,230$ billion, or approximately 15 percent, to the U.S. gross domestic product (fig. 1A), and the Nation's mines and quarries produced raw materials with a total estimated value of $\$ 74$ billion, with production varying by state (U.S. Geological Survey, 2012, p. 5; fig. $1 B$ ). Domestic energy resource production activities also take place throughout the Nation (such as oil and gas production, fig. 2; from Biewick, 2008). In 2011, the United States consumed approximately 7 billion barrels of oil, 24 trillion cubic feet of natural gas, and 1 billion short tons of coal (U.S. Energy Information Administration, 2012). To meet
A. Total gross domestic product in the United States in 2011, \$15,100 billion

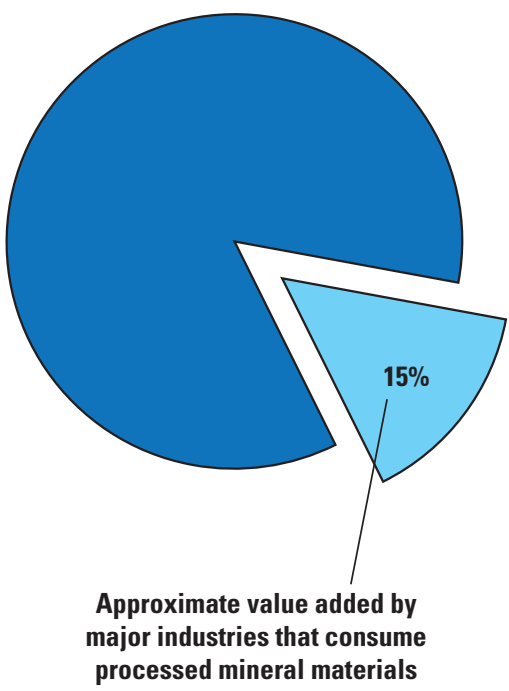

B. Value of nonfuel mineral production in the United States in 2011 (preliminary)

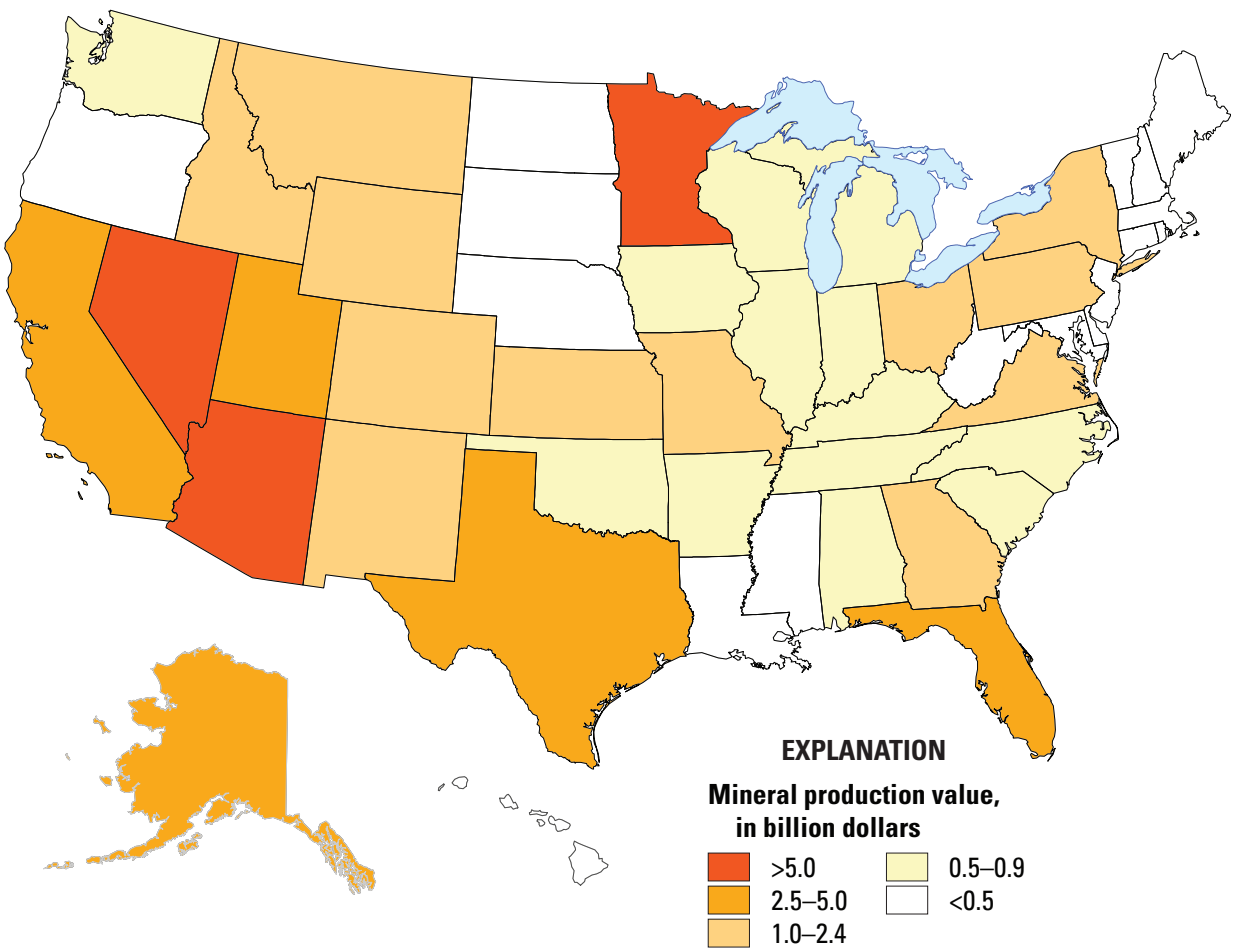

Figure 1. Diagram and map showing the magnitude and distribution of mineral resource production activities across the Nation. $A$, Pie chart depicting the estimated value added to the U.S. gross domestic product by major industries that consume processed mineral materials; major consuming industries of processed mineral materials are construction, durable goods manufacturers, and some nondurable goods manufacturers. $B$, Map showing the [preliminary] value of nonfuel mineral production (raw materials from mining) in the United States in 2011. 
these needs, energy and mineral production (extraction) occurs in every State, with substantial amounts also imported from other countries.

The United States faces challenges in meeting its current (2013) and future energy and minerals needs. These challenges range in scale from global competition for resources to local decisionmaking about the appropriate use of individual land parcels. Decisions on every scale may affect the availability of energy and minerals and have far-reaching economic, geopolitical, and social consequences. For example, the increasing demand for both traditional and emerging energy and mineral resources is driving exploration and production into geological settings for which there may be little data available, such as in the Arctic, deeper in the Earth's crust, and beneath deeper regions of the oceans. Activities in these locations may pose considerable technical and engineering challenges or be colocated with sensitive environments or other natural resources of importance.

At the same time, consideration of alternative sources of energy and minerals is increasing, which may involve mining of deposits of lower concentration, recovering resources from waste and recycling streams, and sourcing from countries with different political systems or environmental stewardship practices. The USGS serves the national interest by providing impartial information across this range of scales and about alternatives, thereby enabling decisionmakers and society at large to make informed decisions and better understand the potential outcomes of those decisions.
An additional challenge facing the Nation is the need to balance the reliability and availability of energy and mineral supplies with other considerations including the availability of other natural resources; the viability of energy and mineral development amidst changes in climate, natural hazards, and demand; and the need to prevent or mitigate environmental degradation (Gundersen and others, 2011). This challenge is especially noteworthy given the long-term nature of resource development and associated infrastructure and the comparable or longer recovery times stemming from any adverse effects. The concept of sustainability, defined as "development that meets the needs of the present without compromising the ability of future generations to meet their own needs" (United Nations World Commission on Environment and Development, 1987, p. 54), underpins many land use and environmental policies that address this challenge. From the perspective of nonrenewable energy and mineral resources, sustainability focuses on stewardship of lands, protection of the environment, and identification of alternative sources.

To provide society with the knowledge needed to address these challenges, there is growing recognition that it is incumbent on "earth scientists to redirect their scientific research, to assemble data that are usable in policy analysis and decisionmaking, and ultimately transmit their findings more clearly to policymakers and the public" (National Research Council, 1996, p. 5). The USGS leads research and monitoring studies to address these challenges and provide a scientific foundation for decisionmaking with respect to sustainable resource

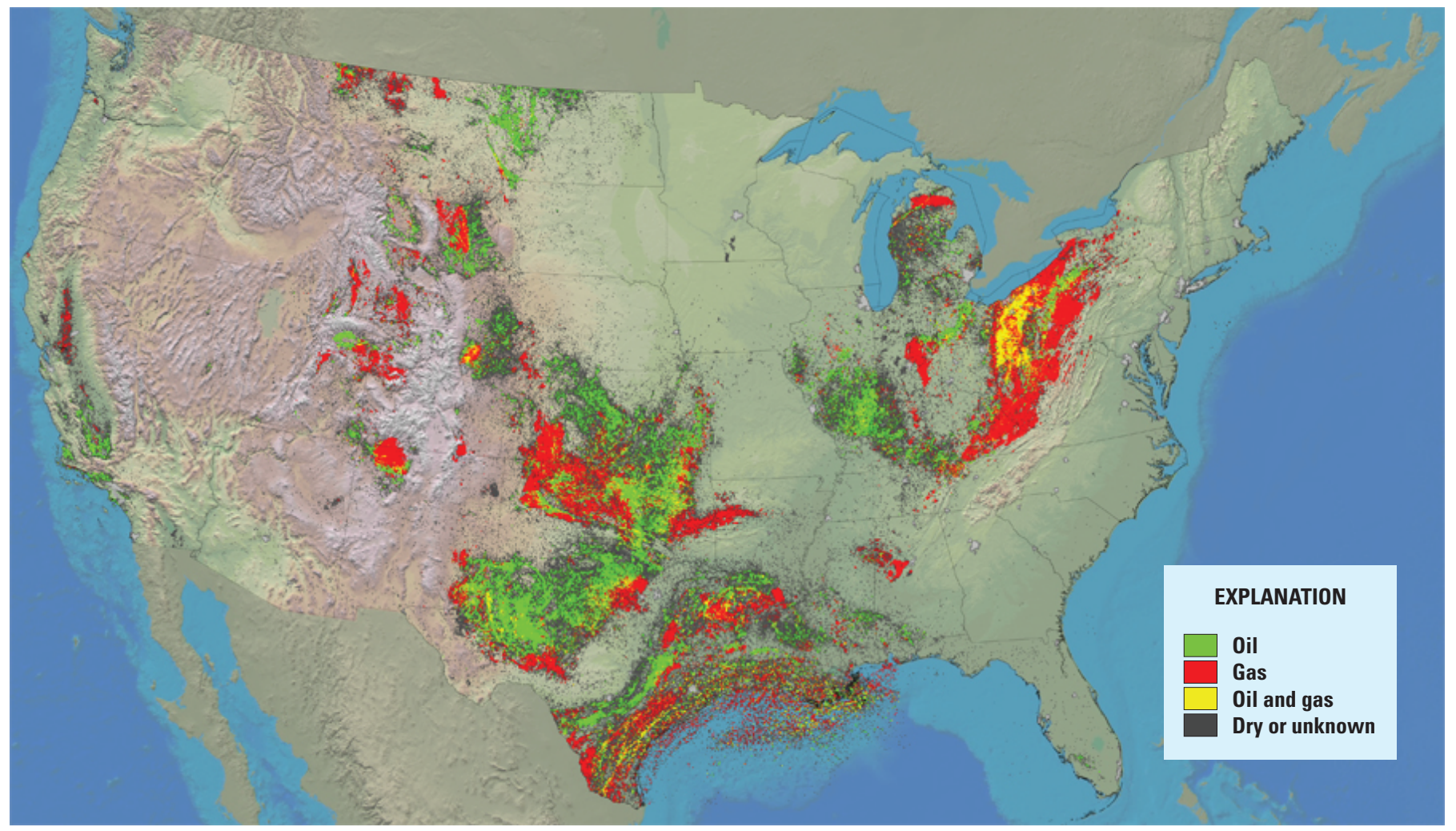

Figure 2. Areas of historical oil and gas exploration and production in the conterminous United States through 2006. 
use, protection, and adaptive management. In this strategy, we identified a set of overarching questions that drive the science needed to address energy and mineral resources use issues during the coming decade. All parts of this science strategy are designed to reflect one or more of these challenges:

- How or where might energy and mineral commodities be obtained to meet present and future needs?

- What economic, environmental, geopolitical, and health consequences must also be considered in both the short term and the long term?

- How can decisions more effectively incorporate scientific complexity and uncertainty?

- What science is needed to anticipate and respond to future events?

Using these questions as a guide, five interdependent goals were constructed that collectively provide the needed scientific research, information, and analysis:

- Goal 1.-Understand fundamental Earth processes that form energy and mineral resources

- Goal 2.-Understand the environmental behavior of energy and mineral resources and their waste products

- Goal 3.-Provide inventories and assessments of energy and mineral resources

- Goal 4.-Understand the effects of energy and mineral development on natural resources and society

- Goal 5.-Understand the reliability and availability of energy and mineral supplies
The overarching concept for these goals is a resource lifecycle for energy and minerals (fig. 3), which traces the flow of these resources from generation and occurrence through interaction with society and the environment to ultimate disposition and disposal.

Each goal addresses one or more stages of the resource lifecycle. Through targeted research, the first two goals expand basic knowledge of the formation of energy and mineral deposits and their interaction with the atmosphere, biosphere, and hydrosphere. The next two goals build on this research foundation and develop additional science and information products. The final goal extends beyond identified concerns to focus and deliver science on emerging issues and unanticipated events affecting energy and mineral supplies.

Together, these goals form a dynamic science strategy for advancing USGS science to a new level of understanding and effectiveness in the next 10 years (table 1). Each goal presents several specific "actions," intended to fill the highest priority needs and address key gaps in data and understanding. Actions range from those that incrementally build on existing USGS capabilities and core strengths to new, ambitious efforts. In most cases, successful achievement of these actions cannot be accomplished solely within the energy and minerals mission area but rather depends on collaboration and leveraging of expertise and capabilities across the USGS and among stakeholders and partners.

Figure 3. A resource lifecycle for energy and minerals. Society faces key decisions within each stage of the resource lifecycle. Scientific understanding is an essential input to these decisions.

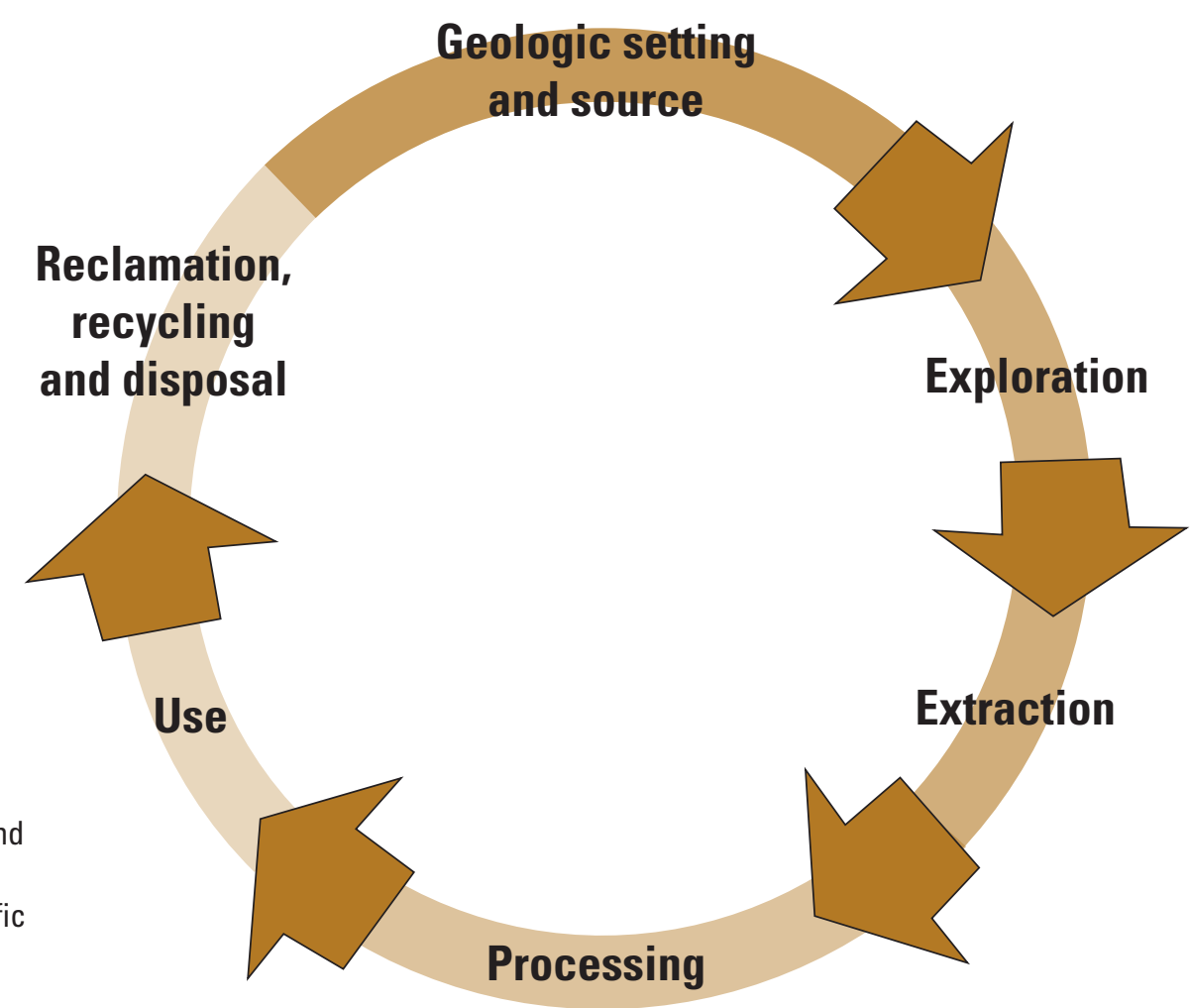


Table 1. Summary of goals and actions for the U.S. Geological Survey energy and minerals science strategy.

\section{Focus area}

Actions

Goal 1: Understand fundamental Earth processes that form energy and mineral resources

1-1 Geologic and tectonic framework studies

$1-1 \mathrm{a} ; 1-1 \mathrm{~b} ; 1-1 \mathrm{c}$

1-2 Evolution of energy and mineral systems

$1-2 \mathrm{a} ; 1-2 \mathrm{~b} ; 1-2 \mathrm{c} ; 1-2 \mathrm{~d}$

1-3 Frontier studies

$1-3 \mathrm{a} ; 1-3 \mathrm{~b} ; 1-3 \mathrm{c}$

Goal 2: Understand the environmental behavior of energy and mineral resources and their waste products
2-1 Fundamental studies
$2-1 \mathrm{a} ; 2-1 \mathrm{~b} ; 2-1 \mathrm{c}$
2-2 Applied investigations
$2-2 \mathrm{a} ; 2-2 \mathrm{~b} ; 2-2 \mathrm{c} ; 2-2 \mathrm{~d}$

2-3 Synthesis activities

$2-3 a ; 2-3 b$

Goal 3: Provide inventories and assessments of energy and mineral resources

$\begin{array}{lll}3-1 & \text { Undiscovered geologically based energy resources } & 3-1 \mathrm{a} ; 3-1 \mathrm{~b} ; 3-1 \mathrm{c} ; 3-1 \mathrm{~d} \\ 3-2 & \text { Discovered nonfuel mineral resources } & 3-2 \mathrm{a} ; 3-2 \mathrm{~b} ; 3-2 \mathrm{c} ; 3-2 \mathrm{~d} ; 3-2 \mathrm{e} \\ 3-3 & \text { Undiscovered nonfuel mineral resources } & 3-3 \mathrm{a} ; 3-3 \mathrm{~b}\end{array}$

Goal 4: Understand the effects of energy and mineral development on natural resources and society

4-1 Spatial analysis of energy and mineral resources occurrence and development 4-1a; 4-1b; 4-1c

4-2 Exploration of interdisciplinary approaches

$4-2 \mathrm{a} ; 4-2 \mathrm{~b} ; 4-2 \mathrm{c} ; 4-2 \mathrm{~d} ; 4-2 \mathrm{e}$

Goal 5: Understand the reliability and availability of energy and mineral supplies

5-1 Sudden disruptions affect supplies 5-1a; 5-1b

5-2 Evolving issues affect long-term availability

$5-2 \mathrm{a} ; 5-2 \mathrm{~b} ; 5-2 \mathrm{c} ; 5-2 \mathrm{~d}$

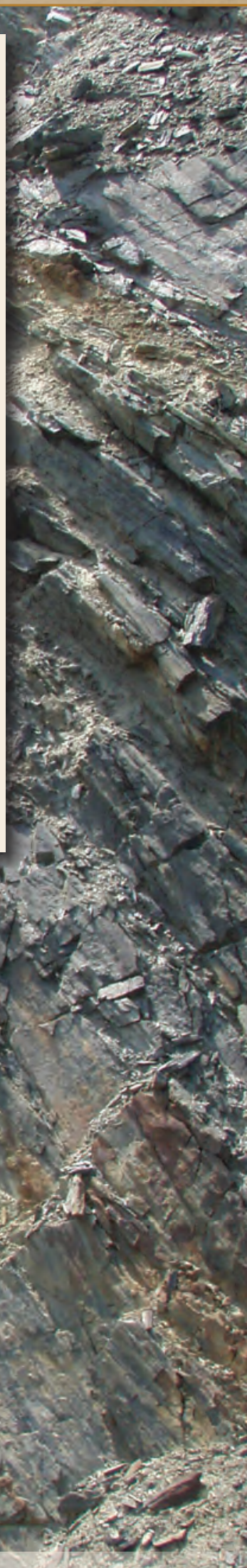

USGS scientist takes an oriented sample of folded, crenulated, and metamorphosed banded siltite, exposed in the Blacktail pit of the Blackbird cobalt-copper mine, in the Salmon River Mountains of east-central Idaho. Photograph by Art Bookstrom, USGS.

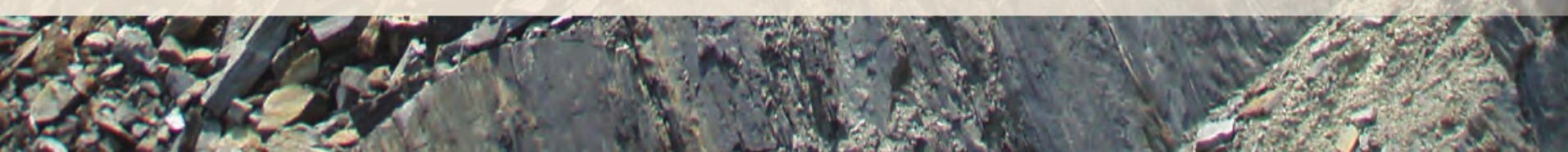




\section{Core Strengths}

The USGS is able to provide essential science products that complement the missions of other Federal and State agencies and others. The USGS performs research ranging from microscopic to global scales and collects and maintains longterm monitoring data that enable study of how systems change through time as well as facilitate construction of predictive models. Having an impartial, global perspective, the USGS can work across agency and jurisdictional boundaries to collect and interpret disparate information.

USGS scientists working on energy and minerals, collectively, have broad experience in energy and minerals research, resource assessment, environmental characterization, data collection, and analysis. A wide variety of customers and stakeholders, each with unique demands for information-from the Secretary of the Interior requesting scientific evaluation for decision support on uranium mining issues to resource evaluations for Congress, Federal agencies, and others-all rely on the vast breadth and quality of information USGS scientists provide, underscoring the importance of maintaining a robust foundation of scientific expertise.

Geologists, geophysicists, geochemists, physical scientists, and economists at science centers are leading energy and minerals research and analysis throughout the energy and minerals resource lifecycle, in areas such as the following: igneous and metamorphic petrology, isotopic and organic geochemistry, marine and economic geology, mineralogy, mineral commodity analysis and materials flow studies, sedimentology, sequence stratigraphy, and tectonics and structural geology. Collectively, this research is applied to the understanding and assessment of fossil fuels and selected nonhydrocarbon energy sources and mineral deposits. Specific examples of energy and minerals research include development of new assessment methodologies; laboratory capabilities for geochemical and mineralogical analyses; geophysical data acquisition and interpretation; minerals information collection, synthesis, and delivery, including development and maintenance of online databases; and dissemination, education, and outreach. In addition, working across the USGS, scientists lead research on the potential environmental and human health effects of energy and mineral use. With this solid foundation in basic research and a recognized flexibility to apply scientific understanding to contemporary issues, the USGS is well positioned to continue providing cutting-edge science on current (2013) and future energy and mineral resources issues.

\section{Mandates and Authorizations}

The USGS was established on March 3, 1879, under the Organic Act of March 3, 1879 (43 U.S.C. \$31), for "classification of the public lands, and examination of the geological structure, mineral resources, and products of the national domain." This legislation stemmed from a report of the National Academy of Sciences, which had been tasked by Congress in June 1878 to provide a plan to secure the most cost-efficient surveying of the territories of the United States. The USGS component stemmed from the need to survey the mineral and water resources of the United States (National Academy of Sciences, 1913). The USGS responsibility and core capabilities for energy and minerals research and information have evolved considerably since the original legislation as the Nation's information and resource needs have increased. Further, with globalization and international demand for energy and minerals, the USGS also works outside the borders of the United States to enhance the understanding of energy and mineral resources relative to global and domestic supplies and thus contribute to national security and economic growth (National Research Council, 2012).

The USGS is responsive to numerous congressional mandates and authorizations and presidential actions pertaining to energy and mineral resources (table 2). Many of these mandates and authorizations recognize, support, and encourage research and assessments developed by the USGS and around which the USGS workforce is formed. For example, the Energy Independence and Security Act of 2007 (P.L.110-140) authorized the USGS to lead storage capacity assessments of carbon dioxide $\left(\mathrm{CO}_{2}\right)$ for the purposes of evaluating geologic sequestration potential. This authorization is a recognition of USGS experience in conducting oil and gas resource assessments and established expertise in Earth sciences, methodologies, and unbiased assessments. 
Table 2. Principal mandates and authorizations related to U.S. Geological Survey energy and minerals activities and their intersection with each of the five goals in the energy and minerals science strategy.

[U.S.C., U.S. Code; P.L., Public Law]

\begin{tabular}{|c|c|c|c|c|c|}
\hline Legislation or presidential action providing authority & Goal 1 & Goal 2 & Goal 3 & Goal 4 & Goal 5 \\
\hline Organic Act of 1879 (43 U.S.C. $\S 31)$ & * & * & * & $*$ & * \\
\hline Strategic and Critical Materials Stock Piling Act of 1946 (50 U.S.C. §98) & $\dagger$ & & $\dagger$ & & $\dagger$ \\
\hline $\begin{array}{l}\text { Transfer of functions from Secretary of Interior to Secretary of Agriculture, } 1960 \\
\text { (7 U.S.C. } \$ 2201 \text {; P.L.86-509) }\end{array}$ & & & $\dagger$ & $\dagger$ & \\
\hline Wilderness Act of 1964 (16 U.S.C. 23; P.L.88-577) & & & $*$ & $*$ & \\
\hline National Environmental Policy Act of 1969 (43 U.S.C. 55; P.L.91-190) & & ** & $* *$ & $* *$ & $* *$ \\
\hline Mining and Minerals Policy Act of 1970 (30 U.S.C. §21a; P.L.91-631) & $\dagger$ & $\dagger$ & $\dagger$ & & \\
\hline $\begin{array}{l}\text { Forest and Rangeland Renewable Resources Planning Act of } 1974 \text { (16 U.S.C. 36; } \\
\text { P.L.93-378) }\end{array}$ & & & $* *$ & ** & \\
\hline $\begin{array}{l}\text { Geothermal Energy Research, Development, and Demonstration Act of } 1974 \\
\text { (30 U.S.C. 24; P.L.93-410) }\end{array}$ & * & & * & & \\
\hline Federal Coal Leasing Amendments Act of 1976 (P.L.94-377) & & & * & * & \\
\hline Federal Land Policy and Management Act of 1976 (43 U.S.C. 35; P.L.94-579) & & & * & $*$ & \\
\hline $\begin{array}{l}\text { National Materials and Minerals Policy, Research, and Development Act of } 1980 \\
\quad(30 \text { U.S.C. 28; P.L.96-479) }\end{array}$ & * & * & * & $*$ & $*$ \\
\hline Alaska National Interest Lands Conservation Act of 1980 (16 U.S.C. 51; P.L.96-487) & & & $*$ & $*$ & \\
\hline Deep Seabed Hard Minerals Resources Act of 1980 (30 U.S.C. 26; P.L.96-283) & & $* *$ & $* *$ & & \\
\hline Nuclear Waste Policy Act of 1982 (P.L.97-425) & & & 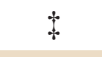 & 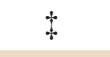 & \\
\hline Geothermal Steam Act Amendments of 1988 (P.L.100-443) & & & * & $*$ & \\
\hline Executive Order 12656-Assignment of Emergency Preparedness Responsibilities & & & & & $\dagger$ \\
\hline Energy Policy Act of 1992 (P.L.102-486) & & & $*$ & & \\
\hline $\begin{array}{l}\text { The Balanced Budget Downpayment Act, I - } 1996 \text { (P.L.104-99 §123) } \\
\text { [Transfer of functions from U.S. Bureau of Mines] }\end{array}$ & & & * & $*$ & $*$ \\
\hline Energy Policy and Conservation Act Amendments of 2000 (P.L.106-469 §104) & & & $*$ & $*$ & \\
\hline Methane Hydrate Research and Development Act of 2000 (P.L.106-193) & * & & & & \\
\hline Energy Policy Act of 2005 (P.L.109-58) & $*$ & & * & $*$ & \\
\hline Energy Independence and Security Act of 2007 (P.L.110-140) & & * & $*$ & & \\
\hline Executive Order 13603 - National Defense Resources Preparedness & & & & & $\dagger$ \\
\hline $\begin{array}{l}\text { Executive Order 13605-Supporting Safe and Responsible Development of } \\
\text { Unconventional Domestic Natural Gas Resources }\end{array}$ & & $\dagger$ & $\dagger$ & $\dagger$ & \\
\hline \multicolumn{6}{|c|}{$\begin{array}{l}\text { *Specifically mentions the U.S. Geological Survey (USGS) or the U.S. Bureau of Mines, whose functions were partially transferred to the USGS in } \\
1996 \text {. }\end{array}$} \\
\hline
\end{tabular}




\section{Goals for Energy and Mineral Resources Science}

\section{Goal 1: Understand Fundamental Earth Processes that Form Energy and Mineral Resources}

\section{Introduction}

From the Earth's crust, energy and mineral resources are extracted for use in our daily lives and to support our economy and national security. Comprehensive studies of the Earth's fundamental processes are necessary to understand the formation and distribution of energy and mineral resources from the surface of the Earth to depths of many kilometers. To achieve this understanding, future research efforts under goal 1 are grouped into three areas:

- geologic and tectonic framework studies

- the evolution of energy and mineral systems

- new research in frontier areas

The following sections present key scientific questions for each of these three areas and strategic actions to address these questions. These targeted research actions, which illuminate the conditions under which reservoirs and deposits form and where they occur, also lead to clearer identification of those aspects of formation and accumulation that may cause problems when exposed at the surface of the Earth or extracted from the Earth (goal 2) and allow clearer delineation of the amount, location, and character of resources potentially available (goal 3).

\section{1-1. Geologic and Tectonic Framework Studies}

Regional-scale geologic studies integrate tectonic and thermal evolution of basement and basin terranes, occurrence and flow of subsurface fluids, and fluid-rock interactions. Regional-scale geologic studies provide the geologic framework that will improve understanding of the formation of oil and gas accumulations and mineral deposits at smaller spatial scales. Outcomes from these studies provide the scientific basis and guidelines for energy and mineral resources mapping and assessments (goal 3). The research activities on geologic processes expressed here and the assessment research activities considered in goal 3 are strongly interrelated because the outcomes of geologic research may alter assessment methodology, and questions uncovered during assessment work may spawn new geologic research activities.

Regional-scale geologic framework studies at the USGS have been limited by incomplete spatial coverage of seismic reflection, gravity, and magnetic data, which provide images of the subsurface and are a prerequisite to conducting structural analyses at the regional scale. With a few important exceptions, the seismic reflection data that the USGS has acquired are sparse and outdated and do not reflect the technological improvements of the past 30 years. Existing national gravity and magnetic datasets are composites of surveys acquired over many years at different scales of spatial coverage with consequent gaps in coverage.

Typically, new data are acquired by topical studies without a plan of systematic acquisition. Although the main barrier to acquisition is cost (seismic data are usually purchased from vendors; augmentation of magnetic and gravity data requires new surveys), other avenues could be pursued to acquire data. Having access to a suite of deep-penetrating, crustal-scale geophysical data would improve views of the subsurface, and research based on these data will better reflect the "stateof-the-art" technologies. Merging this new information with stratigraphic, structural, and other geophysical studies would support more accurate basin histories and provide better understanding of the formation of energy and mineral deposits.

The high data densities produced by studies on selected areas require new means of integrating multidisciplinary datasets. Interpretations of different datasets from separate analyses can produce incompatible results when viewed together. Thus, the attainment of consistent geological results benefits from mutual usage of a shared interpretive platform. Collaborative work is done more easily when viewed on interactive three-dimensional (3D) systems that provide the ability to slice and section 3D models at varying elevations and azimuths, complementing and gradually superseding the traditional presentations of selected map and cross sections (see Highlight, p. 9). Incorporating a wide range of subsurface information, 3D models facilitate improved understanding of geologic processes. Such software systems will continue to evolve and provide improved capability for multidisciplinary collaboration.

\section{Major Questions}

- How does the thermal, magmatic, tectonic, and fluidflow history of the Earth lead to the formation and later modification of energy and mineral deposits?

- What enhancements to geophysical and geochemical data are required to support crustal- and deposit-scale geological interpretations?

- How can multidisciplinary studies of a region or terrane consistently be interpreted and presented to users?

\section{Strategic Actions}

- Action 1-1a.-Map regional-scale geologic features that control the timing and location of energy and mineral resources. Identify key areas for regional-scale structural and geologic mapping and use geophysical, geochemical, and isotopic studies to determine areas with resource potential. This action will result in 


\section{The Advantages of Three-Dimensional Models and Visualization}

Traditional USGS geoscience products have been generated and distributed primarily through the medium of twodimensional reports, maps, and cross-sections, limiting the ability to characterize and understand three-dimensional (3D) systems and how they change through time (4D). And yet, the intrinsic 3D and 4D nature of the interpreted results increases the need for the USGS to generate and distribute scientific information using 3D and 4D visualization frameworks. In addition, Web-based delivery in 3D and 4D frameworks could open a new era in USGS publications.

Today, USGS scientists use $3 \mathrm{D}$ and $4 \mathrm{D}$ tools to visualize and interpret geologic information and to check the data, interpretations, and models (Jacobsen and others, 2011). The use of 3D and 4D visualization can be a powerful quality control tool in the analysis of large, multidimensional datasets. Examples of geologic mapping in 3D include aquifer characterization, the interpretation of geophysical data with geological constraints, subsurface characterization of mineral systems, and oil and gas investigations. For example, a 3D geologic model served as input to a 4D computation of heating and oil generation during subsidence of the Anadarko Basin of Oklahoma (fig. 4; Higley, 2008). The Woodford Shale in the Anadarko Basin in Oklahoma is the source of much of the oil and gas in the basin. The transformation of kerogen, a fossilized form of organic matter, to oil was computed as a function of geologic time and displayed on cross sections [at 300 million years ago (Ma) and $0 \mathrm{Ma}$ ]. Other useful displays (not depicted in figure 4) reveal the migration of oil and gas at different geologic times from the deep basin to reservoirs on the flanks of the basin.

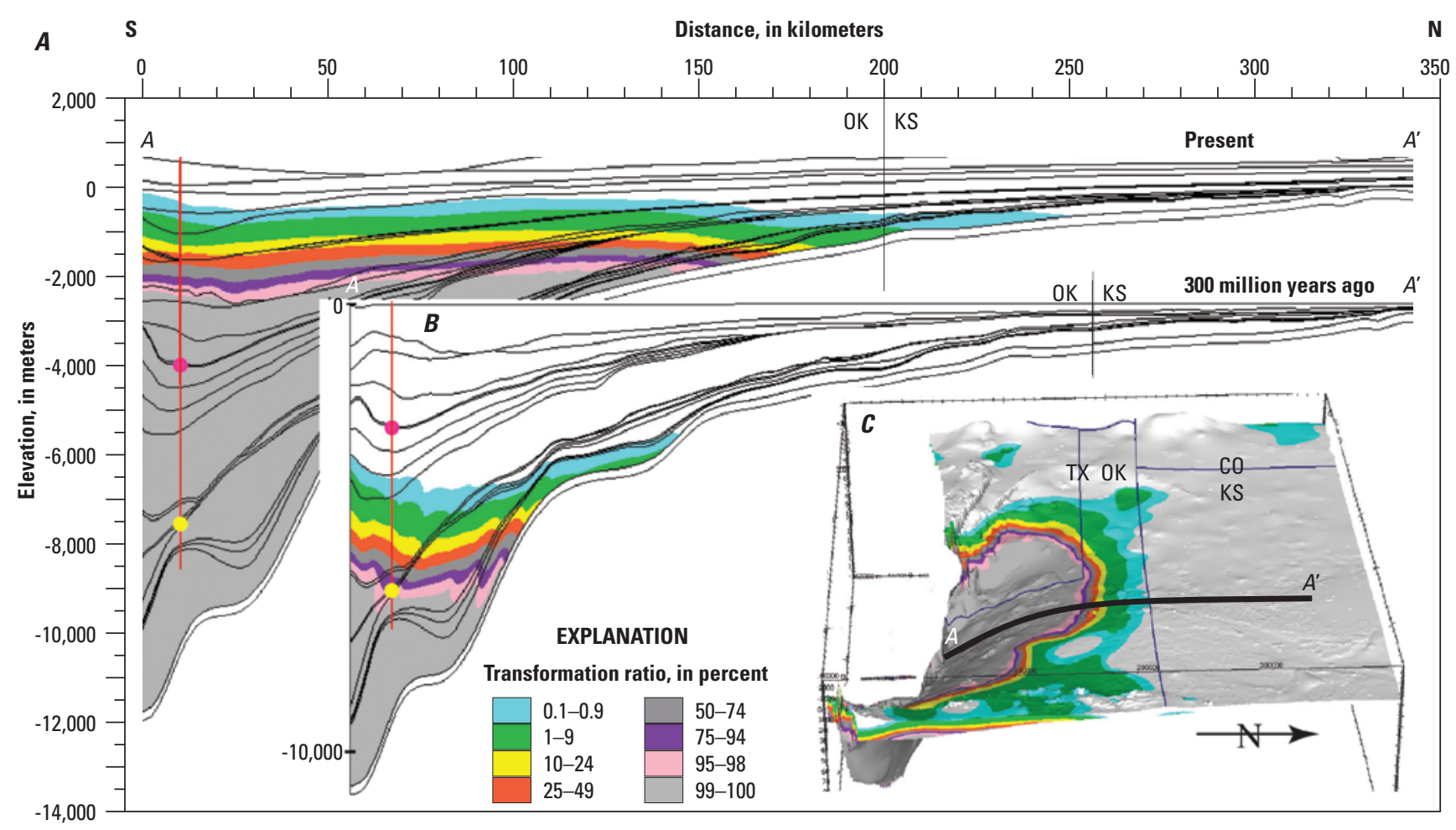

Figure 4. Geologic model output showing a south-to-north cross section $\left(A-A^{\prime}\right)$ at $A$, present day, and $B$, inset, 300 million years ago, and $C$, inset, a 3-D model of thermal maturation using Woodford Shale transformation ratio. Yellow and pink dots are approximate locations of the Woodford Shale and Thirteen Finger limestone. Elevation is relative to sea level, and vertical and lateral scales are equivalent for the cross sections. The black line in the $3 \mathrm{D}$ model shows the location of the cross-section $A-A^{\prime}$. Map image is transformation ratio on the Woodford Shale layer at present day and at 10 times vertical exaggeration. 
improved geologic models, maps, and cross sections, revealing those areas where energy and mineral resources are most likely to be found in the United States.

- Action 1-1b.-Acquire geophysical datasets at the regional scale. Such an effort would require a systematic, multiyear program to facilitate the acquisition of seismic data in sedimentary basins and upgrade the existing national magnetic and gravity datasets.

- Action 1-1c.-Apply 3D models to areas of high potential for energy and mineral resources, incorporating geologic mapping, thermotectonic, fluid-flow, and geophysical interpretations. Such models will ensure compatibility of data and interpretations from multiple disciplines and broaden the user base because geological and geophysical interpretations may become more readily available in a user-friendly format.

\section{1-2. Evolution of Energy and Mineral Systems}

An exploitable petroleum (oil, natural gas, and natural gas liquids) system encompasses the source rock, the rocks adjacent to source rocks, migration pathways, and reservoirs. Source rocks that are the locus of petroleum generation may also contain developable resources, such as shale gas and shale oil. Rocks adjacent to source rocks (such as those in tight gas systems), formerly not developed, are now routinely exploited in the conterminous United States. Thus, source rocks and tight rocks are two types of continuous petroleum systems supplying a rapidly expanding fraction of hydrocarbons, especially gas. Fluid migration pathways and charge mechanisms in these geologic settings continue to be elusive, poorly understood, and minimally studied. Despite advancements in seismic and well-logging technologies, the productivity of continuous petroleum systems is not readily predictable and often must be determined empirically.

Energy resources contributing to the U.S. energy mix in 2013 (for example, oil, gas, coal, coalbed methane) are fairly well understood in terms of their geologic formation and occurrence. For these resources, we identify research priorities pertaining to environmental effects (goal 2) and assessments (goal 3). Other resources, such as oil shale, gas hydrates (also referred to as methane hydrates), and geothermal energy, which contribute little (or not at all) to the U.S. energy mix, are not as well understood. Because these resources have the potential to make significant contributions to the energy mix in the future, we identify research activities to address the many geologic and extractive questions pertaining to these emerging resources.

The concept of a mineral system is analogous to that of a petroleum system, in that formation of an ore deposit requires a source of metals, a mode of transport (often a hydrothermal fluid but also magmatic, weathering, petroleum generation, or sedimentary processes), and a site of deposition or accumulation where metals are concentrated to an extent that allows economically viable extraction. However, mineral systems are found in a wider range of rock types and structural settings than petroleum systems. Mineral systems must be understood in their broadest possible context to support accurate resource assessments on regional, national, and global scales. For example, understanding the role of magmatic arcs in the geologic evolution of North America is critical for understanding the genesis and localization of hydrothermal and epithermal mineral deposits. Such focus on the evolution of geologic entities and mineral systems on a geologic-system-scale will lead to more effective ore deposit models and resource assessments.

The state of knowledge varies considerably among deposit types; some deposit types that are becoming important owing to emerging national demand, such as platinum group metals (PGMs), rare earth elements (REEs), and lithium, are not well understood, and focused research would benefit from deposit-scale studies. Other mineral systems, such as porphyry copper deposits, are well understood in terms of their origin and evolution. Future research on these systems would benefit from a broader approach, such as understanding the distribution and geologic evolution of magmatic arcs in which porphyry deposits form.

\section{Major Questions}

- What are the most important factors affecting the development of self-sourced and low-permeability (tight) petroleum systems, and how can this knowledge be applied to ongoing energy assessment needs?

- What areas of research will advance our understanding of emerging and high-priority mineral and energy sources?

- What are the primary controls on the timing and location of ore deposits, and in particular what are the factors that lead to formation of deposits of scarce commodities?

\section{Strategic Actions}

- Action 1-2a.-Investigate the geologic and geochemical factors that are responsible for the genesis, evolution, and productivity of source rocks and low-permeability reservoirs, that is, shale gas, shale oil, and tight gas. The improved understanding of the systematics of self-sourced and low-permeability systems can be used to improve resource assessments.

- Action 1-2b. - Conduct research on emerging energy resources to address geologic and extractive questions. In particular, studies on the chemistry of oil shale (see Highlight, p. 11) and the conditions from which gas hydrates accumulate would be useful. 


\section{Oil Shale: Evaluating an Energy Resource and lts Extractive Effects}

Oil shale potentially can constitute a very large untapped oil resource if the solid kerogen, a fossilized form of organic matter in the rock, can be converted into liquid oil. Decades of field work by U.S. Geological Survey geologists determined that the Green River Formation, which hosts kerogen-rich rocks such as the Mahogany oil shale zone (fig. 5; Mercier and Johnson, 2012), was deposited in a single large lake that covered the Piceance and Uinta Basins and the intervening Douglas Creek arch and that many rich and lean oil shale zones could be traced between the two basins. Combined with assay data, the correlation work was vital in establishing estimates of the total in-place oil shale resources, recently assessed by the USGS to be 1.5 trillion barrels of oil in the Piceance Basin and 1.3 trillion barrels in the Uinta Basin (U.S. Geological Survey Oil Shale Assessment Team, 2010a,b).

To convert kerogen into liquid oil, the rock must be heated to between 350 degrees Celsius $\left({ }^{\circ} \mathrm{C}\right)$ and $500^{\circ} \mathrm{C}$. To achieve a high enough temperature, the rock must either be mined and retorted or else heated electrically in the subsurface with the oil recovered from wells. Environmental issues include significant amounts of water for mining and retorting, surface disturbance (either for mining or for wells required for in situ conversion), greenhouse gas emissions generated during retorting, the disposal and reclamation of spent solids if mining and retorting is employed, and the migration of groundwater contaminated with organic and metallic compounds if in situ conversion is used. Laboratory research is underway at the USGS to document the chemistry of waste products. A major concern is the presence of metals, such as arsenic and mercury, and volatile and dissolved organic compounds.

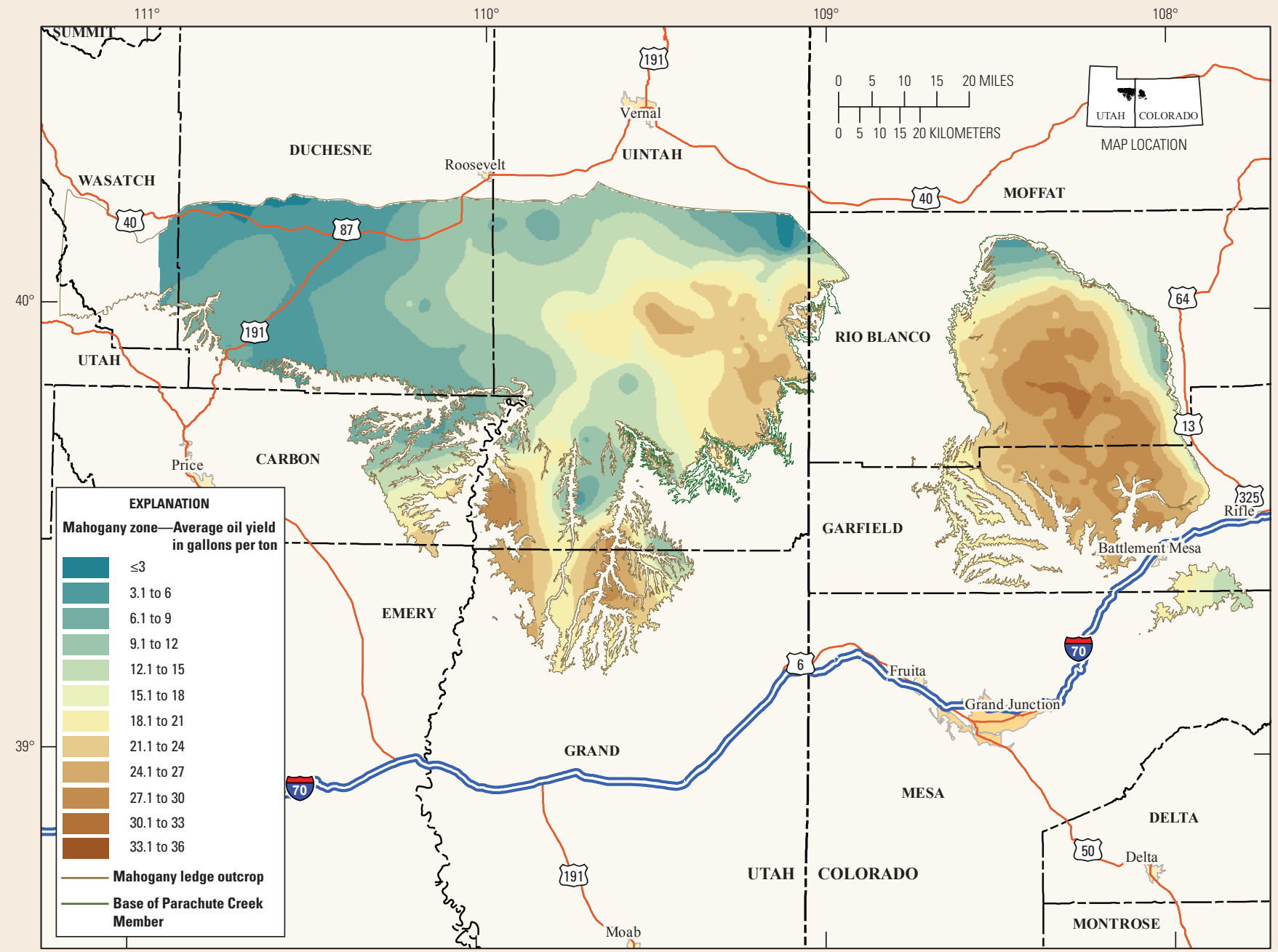

Figure 5. Isoresource map of Mahogany oil shale zone in Uinta and Piceance Basins showing oil yield in gallons per ton. Oil yield is calculated from Fischer assay, formation thickness, and areal extent. 
- Action 1-2c.-Conduct deposit-scale studies of selected types of high-priority commodities, such as lithium, REEs and PGMs. The genetic models that are generated by such studies will characterize the geologic setting and abundance of important materials on land and on the sea floor and aid in assessments of such resources (goal 3).

- Action 1-2d.-Determine broad-scale controls on the formation and preservation of mineral systems. These studies could target systems that are well understood in terms of how they form, such as porphyry copper deposits.

\section{1-3. Frontier Studies}

Many of the mineral resources in the United States, at least those exposed at the surface, have been identified, and many are being exploited. However, frontier geographic areas, such as the Exclusive Economic Zone (EEZ, see Highlight, p. 14) and Alaska, are largely unexplored, and many areas of the United States may contain resources that are not exposed at the surface. Such areas require novel or "frontier" approaches or methods for exploring and assessing the potential of undiscovered resources.

Exclusive Economic Zone.-The mineral potential of the vast area of the EEZ is little known. Research in the underexplored EEZ is needed because the marine deposits of the area host a wide variety of rare metals and REEs, which are essential to emerging, green, and high-technology applications (Hein and others, 2005). Fundamental research on processes instrumental in concentrating metals into ore deposits in the deep ocean can be carried out while the type and distribution of the deposits are being surveyed. These research results could provide a framework to support future assessments of deep-ocean mineral potential. Collaborative work with USGS coastal and marine scientists, other Federal agencies, university scientists, and oceanographic institutions will improve the quality and utility of these studies.

Beyond the EEZ is the Extended Continental Shelf (ECS), as defined by the United Nations Convention on the Law of the Sea (UNCLOS) (United Nations, 1982). The ECS can be established by coastal nations based on specific geologic and geomorphologic criteria. The potential ECS of the United States could significantly increase the size of the already expansive EEZ, especially north of Alaska in the Arctic Ocean. The ECS of arctic Alaska is a poorly understood tectonic region for which fundamental crustal geological questions must be resolved for both territorial resolution and resource delineation. International collaborative studies can potentially optimize research on the geologic framework and the endowment of energy and mineral resources, which are currently (2013) unknown but likely to include oil and gas, gas hydrate, and rare and critical metals.
Alaska.-Similar to the ECS of arctic Alaska, some landward portions of Alaska are still unexplored, with world-class mineral deposits still being discovered at the surface. Alaska contains vast resources of coal and other fossil fuels, significant potential for geothermal energy, some of the world's largest zinc, copper, and gold deposits, as well as deposits of high-demand mineral commodities, such as REEs, indium, and tin. However, baseline geoscience data for Alaska are incomplete and of lower resolution, are available in smaller quantities, and are not as recent as corresponding data for the conterminous United States. The upgrading, updating, and maintaining of geoscience base data for Alaska are important for supporting USGS efforts to conduct energy and mineral resources assessments.

Concealed resources. - Most of the conterminous United States has been effectively explored on the surface for the presence of mineral resources. Undiscovered resources lie beneath cover (rocks, colluvium and alluvium, and water) that conceals a resource from recognition. One of the key challenges and opportunities the USGS faces in the future is assessing resources under cover and in deep settings [more than 1 kilometer $(\mathrm{km})$ below land surface]. Recent efforts by the USGS, industry, and academia have been initiated to develop methods for exploring beneath cover and to develop geologic frameworks (goal 1-1) that incorporate source, transport, and trap mechanisms to predict where deposits formed and where they should be today. In addition, there is work underway to develop better and more powerful deep-penetrating geochemical and geophysical methods and technology to help visualize those targets, but there is no coherent protocol for estimating the possibility or probability of undiscovered resources beneath cover. Application of new methods and protocols for covered regions will give the USGS the ability to make more objective, repeatable, and reliable assessments of undiscovered resources. The identification of covered mineral resources, particularly in the western United States, also can yield important information for environmental and hydrologic studies.

\section{Major Questions}

- What are the dominant processes that result in a concentration of metals in the deep ocean, and what are the geological, geochemical, and geophysical characteristics that distinguish these deposits?

- What are the geologic data needs in Alaska and the Arctic?

- What are the processes that enhance the surface expression of subsurface resources, and what are the geological, geochemical, biological, and geophysical characteristics that can be used to assess concealed resources? 


\section{Strategic Actions}

- Action 1-3a.-Promote the collection of the geological, geophysical, and geochemical data within the U.S. EEZ. This effort will require collaborations with coastal and marine programs, oceanographic institutions, and other government agencies, such as the Bureau of Ocean Energy Management (BOEM), on relevant oceanographic, geological, and geochemical process research.

- Action 1-3b.-Expand collection and evaluation of geological, geophysical, and geochemical field data for energy and mineral resources in Alaska and the Arctic offshore. Prioritize regions in Alaska in which significant upgrades in base data, satellite imagery, and geophysical, geochemical, and geologic maps are required. This activity would benefit from coordination with the State of Alaska and other government agencies, the academic community, and industry.

- Action 1-3c.-Construct geologic frameworks for concealed deposits. These frameworks would be based on source, transport, and trap mechanisms to predict where deposits are formed, where they occur, and what features can be detected at the surface.

\section{Helicopter drop off for USGS scientist to collect a granodiorite rock sample on a ridge top in the Western Alaska Range. Photograph by John Jackson, USGS.}




\section{Minerals in the U.S. Exclusive Economic Zone}

The U.S. Exclusive Economic Zone (EEZ) comprises all marine areas within 200 nautical miles of the nearest U.S. land, including Pacific islands of U.S. affiliation (Hein and others, 2005), a total area approximately 20 percent greater than the entire U.S. land area (fig. 6A; U.S. Commission on Ocean Policy, 2004). The United States has sovereign rights for the purpose of exploring, exploiting, conserving, and managing natural resources in the EEZ. These resources include deep-ocean strategic and critical minerals essential for national security and economic growth, especially in high-technology and green applications.

Deposit types that have promising resource potential are sea floor massive sulfides, ferromanganese crusts, manganese nodules, and phosphorite. Significantly, some of these deep-ocean mineral deposits have high concentrations of rare earth elements, precious metals, base metals, and many other resources, but the resource potential of these deposits is yet to be determined. In fact, reconnaissance minerals data do not exist for substantial parts of the EEZ. The knowledge base of the USGS combined with published and unpublished databases and collections of new data can be used for resource and environmental evaluation and development of deposit models. USGS resource assessment techniques developed for land-based deposits may have applications for offshore deposits once sufficient relevant data for the EEZ have been collected on research cruises specifically designed to study mineral deposits.

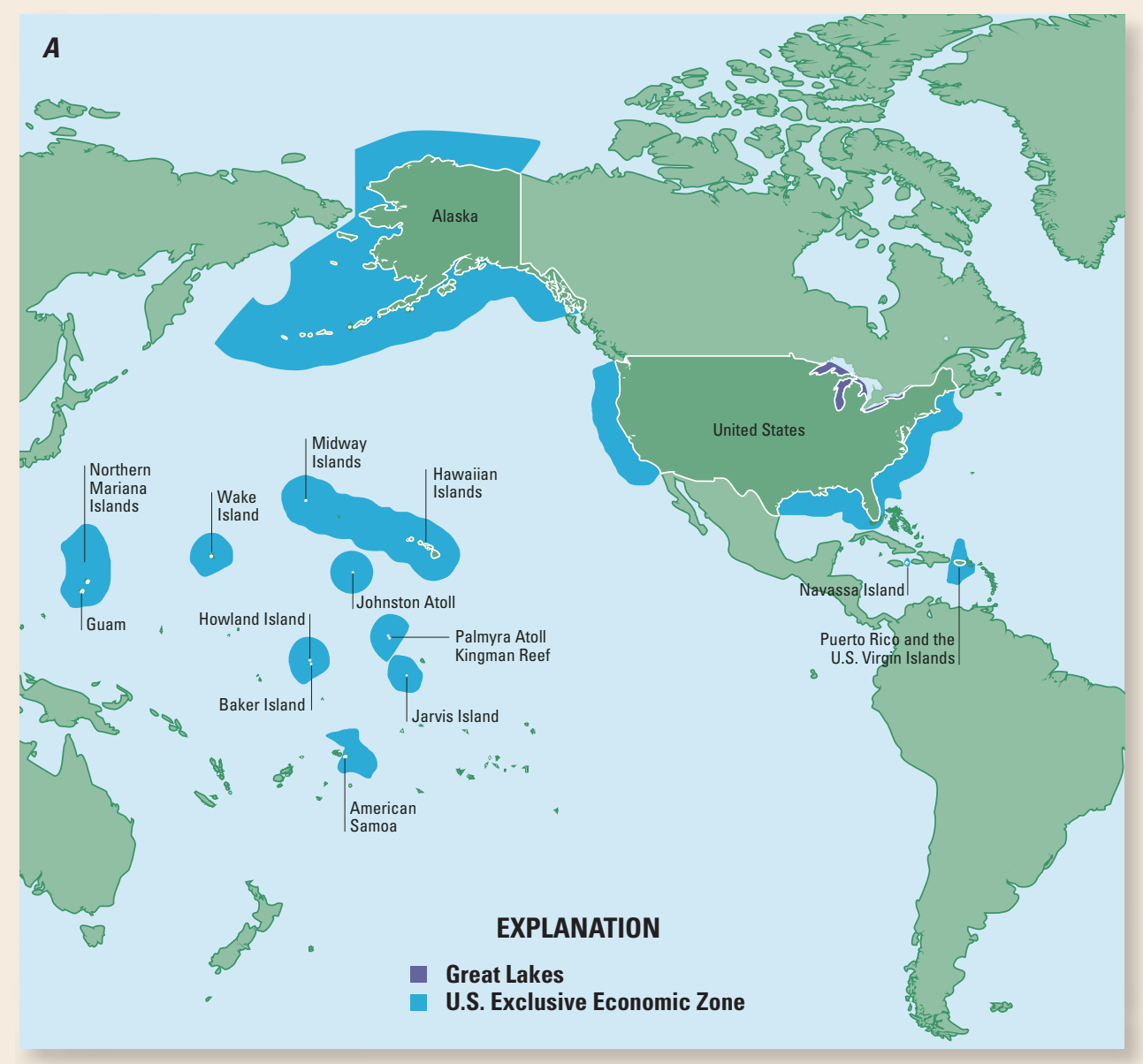

Figure 6. $A$, Map showing the U.S. Exclusive Economic Zone (EEZ; blue shaded areas). $B$, Clockwise from upper left: 13.6-centimeter $(\mathrm{cm})$ diameter nodule from Marshall Island in the EEZ; three abyssal nodules, each $3 \mathrm{~cm}$ in diameter, from the Clarion-Clipperton prime nodule zone (international waters); cross-section of nodule from the Blake Plateau off the coast of Florida, Georgia, North Carolina, and South Carolina; diagenetic nodules in a box core from the Peru Basin; and dense concentration of nodules rich in nickel, copper, lithium, and molybdenum located in an area about 4 meters $(\mathrm{m})$ by $3 \mathrm{~m}$ of the Johnston Atoll EEZ.

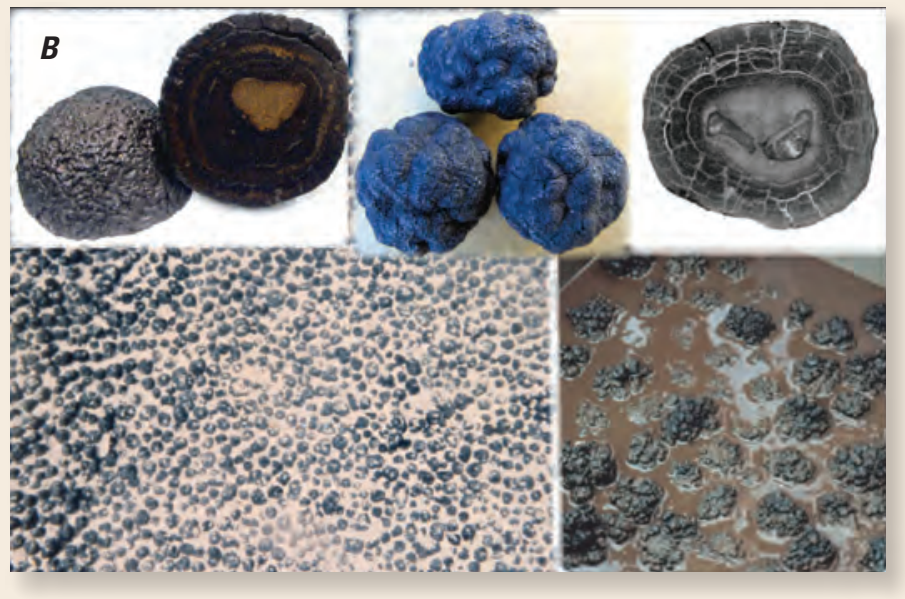




\section{Goal 2: Understand the Environmental Behavior of Energy and Mineral Resources and Their Waste Products}

\section{Introduction}

The research challenges associated with sustainability of energy and mineral resources and the environment are woven together in a complex tapestry that spans the entire lifecycle of resource development from the geologic setting of formation and occurrence through exploration, extraction, processing, and use to reclamation, recycling, or disposal and beyond. A more comprehensive understanding of the interactions among energy and mineral resources and environmental and biological receptors can help the following: resource industries to identify efficient and cost-effective means of mitigating adverse environmental effects, land use managers and regulators to ensure proper stewardship and protection of the environment, and citizens to be informed about risks and benefits associated with resource extraction (National Research Council, 2007). Furthermore, research characterizing these interactions will provide a basic scientific foundation needed to analyze these risks and benefits, sometimes referred to as a "full cost accounting," with the aim of facilitating scientifically informed decisionmaking regarding the sustainable development of energy and mineral resources.

Global economic growth likely will maintain the demand for those energy and mineral commodities that have traditionally formed the staples of society, including aluminum, coal, copper, gas, gold, iron, lead, oil, silver, uranium, and zinc. This demand likely will drive resource exploration in less accessible geologic environments, such as deeper in the Earth's crust and offshore, production of larger deposits of lower grade, and technological advances that enable new resource recovery methods. For example, the production of natural gas from shale formations using hydraulic fracturing, also referred to as "fracking," is increasing, but the potential effects of this technology on water quality and surface-water hydrology are not well understood.

Increased demand for emerging commodities (such as REEs used in permanent magnets for wind turbines and hybrid-car batteries; lithium used in batteries for hybrid cars and other uses; and potash and phosphate in mineral fertilizers needed for biofuel production) will present additional unique environmental challenges and opportunities. These commodities fall into two main categories: those that are the primary target of mineral production, such as most REEs, lithium, PGMs, potash, and phosphate, and those that are produced as byproducts of other commodities, such as gallium, indium, cadmium, tellurium, and some REEs (see Highlight, p. 16). In many cases, these commodities are derived from geologically and mineralogically unique deposit types that require specialized ore-processing techniques to extract the metals, which result in unconventional wastes. Collectively, these future trends in resource production will lead to a host of new environmental challenges requiring cutting edge scientific insights to solve, in addition to addressing existing, unsolved environmental challenges associated with traditional resource recovery and use.

As the United States plans its energy and minerals future, it must be cognizant that some previous extraction and development activities have had adverse environmental effects. Research at legacy resource extraction sites can provide insights into potential alternative sources of resources through reprocessing of waste streams or beneficial reuse. Furthermore, studies at legacy sites can provide understanding of long-term biogeochemical processes influencing environmental signatures; insight into complex natural exposure routes to surrounding ecosystems and humans; and information needed for mitigation and remediation as well as to inform responsible resource development in the future.

The strategic research actions presented in this section outline opportunities for the USGS that can be tailored to advance the state of knowledge of environmental research for a number of different commodities throughout the resource lifecycle. These strategic actions present numerous opportunities for partnering with other Federal agencies, including (but not limited to) resource stewardship and regulatory agencies such as the Bureau of Ocean Energy Management; the Bureau of Land Management; the National Institutes of Health; the National Park Service; the Office of Surface Mining, Reclamation, and Enforcement; the U.S. Army Corps of Engineers; the U.S. Environmental Protection Agency; the U.S. Fish and Wildlife Service; and the U.S. Forest Service. Likewise, partnership opportunities also exist at local, regional, and State levels, such as State geological surveys, as well as private industry for advancing our understanding of the relation between energy and mineral development and the environment.

\section{Major Questions}

- What processes enhance or limit fate and transport, including toxicological effects, of contaminants associated with energy and mineral resources in natural settings?

- Can we distinguish between natural backgrounds and concentrations of elements enhanced by human activities?

- How can we best transfer insights gained from laboratory studies to large-scale field settings and improve the transfer of scientific insights from basic research to field applications?

- Are there chemical and physical characteristics of emerging energy and mineral resources that determine beneficial reusability, byproduct recovery, environmental effects, or appropriate disposal options? 


\section{Renewable Energy and Nonrenewable Mineral Resources}

Significant amounts of nonrenewable mineral resources will be needed to support the growing demand for domestic renewable energy, requiring knowledge about both the sources and the environmental effects of using these minerals, also referred to as energy-critical elements (American Physical Society and Materials Research Society, 2011). For example, many of these mineral commodities come from foreign sources; rare earth elements (REEs), which are used to manufacture magnets for wind turbines and hybrid car batteries, currently (2013) are mined almost exclusively in China. Diversifying REE supplies may prove challenging, as the mineral deposits that yield REEs are atypical with respect to environmental challenges associated with mining and are poorly understood. Similarly, the manufacture of new, higher efficiency or lower cost photovoltaic cells (fig. 7) relies on mineral commodities such as cadmium, gallium, germanium, indium, selenium, and tellurium, which typically are produced as byproducts of the mining of metals such as copper and zinc. Significant amounts of these technologically important commodities may occur in waste piles from historical mines where ore beneficiation techniques were not designed to recover these elements. In addition, transferring electricity generated by solar "farms" to market would require an expanded electrical grid, spurring demand for copper wire. Environmental protection and stewardship of lands associated with future mining for all these mineral commodities will rely on a sound scientific understanding of the source, transport, and fate of all potential contaminants associated with the deposit types that will yield these commodities.

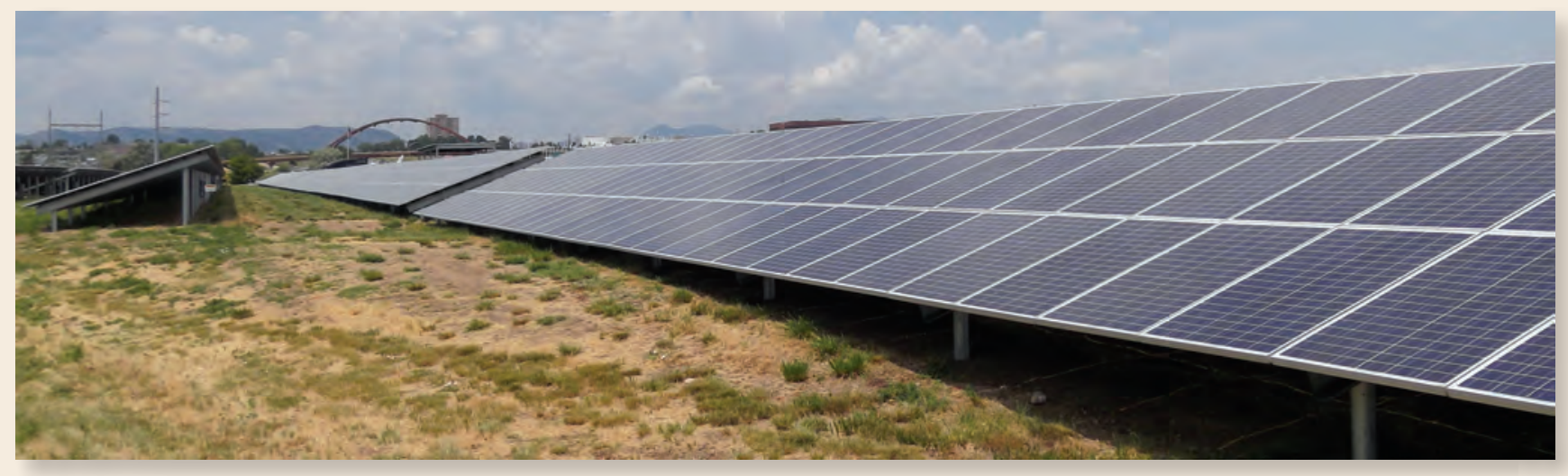

Figure 7. Solar panels installed at the Denver Federal Center in Lakewood, Colorado. Renewable energy sources such as solar energy from photovoltaic cells are reliant on a number of nonrenewable mineral commodities, such as arsenic, cadmium, gallium, selenium, and tellurium.

- How will climate change affect the environmental characteristics of energy and mineral waste associated with past, present, and future production?

- How significant are greenhouse gas emissions or removals associated with energy and mineral production relative to global greenhouse gas budgets?

\section{Strategic Actions}

\section{2-1. Fundamental Studies}

- Action 2-1a.-Investigate carbon sources and potential sinks associated with energy and mineral resources and renewable energy production to improve understanding of carbon cycling. Carbon dioxide release from limestone during cement manufacturing, $\mathrm{CO}_{2}$ in geothermal waters and methane leakage from shale-gas production represent examples of sources of carbon. Likewise, magnesium and calcium-silicate minerals in mine waste represent sinks for atmospheric $\mathrm{CO}_{2}$.

- Action 2-1b.-Investigate perturbations to the natural landscape during the resource lifecycle. Multidisciplinary research studies at both legacy and active energy and mineral production sites will assist in discerning the differences between natural background and anthropogenic effects of energy and mineral development.

- Action 2-1c.-Develop studies to understand the role of climate in altering natural background environmental signatures of energy and minerals systems and the behavior of waste products from energy and mineral development. This understanding is essential for 
devising effective mitigation or remediation strategies for proposed, ongoing, or legacy mining activities or for predicting behavior of wastes under variable climate regimes.

\section{2-2. Applied Investigations}

- Action 2-2a.-Characterize waste streams associated with energy and mineral production and processing. These studies will improve the understanding of the linkages between the energy and mineral resources characteristics and waste products, of opportunities for recycling and byproduct resource recovery, and of mitigation, management, or remediation of contaminant releases to the environment from these wastes.

- Action 2-2b.-Conduct research on deep geologic reservoirs for disposal of wastes from energy and mineral development, extraction, and use. Candidates for disposal in deep geologic reservoirs could include: uranium-contaminated groundwater produced during in situ recovery, high-salinity water coproduced with oil and gas; $\mathrm{CO}_{2}$ generated from fossil fuels (geologic carbon sequestration); and spent nuclear fuel and highlevel nuclear waste.

- Action 2-2c.-Investigate the environmental geochemistry of emerging production technologies. Such insights will be invaluable in designing methods to perform resource assessments and integrated assessments of future resource development (goals 3 and 4). These technologies could include a number of in situ or leaching techniques such as in situ conversion of oil shale (see Highlight, p. 11), in situ leach mining for copper and uranium recovery, hydraulic fracturing for shale gas production, and gas hydrate recovery using hot water, steam injection, and depressurization.

- Action 2-2d.-Expand USGS capabilities for research on the minerals commodities and geologically based environmental effects associated with the growing use of renewable energy resources (biomass, geothermal, hydropower, solar, and wind) to provide information for assessment activities.

\section{2-3. Synthesis Activities}

- Action 2-3a.-Create geologically based environmental models. These models, known as geoenvironmental models (duBray, 1995), can include priority, conventional energy resources (such as coal and uranium) and emerging critical mineral and energy commodities, such as shale gas and REEs. This extension of geoenvironmental models will assist in understanding the geological and geochemical controls on contaminant transport and fate, identifying potential environmental risks, identifying data gaps, and improving energy and mineral resources assessments.

- Action 2-3b.-Enhance the ability to transfer insights between simple process-oriented, short term, and small-scale laboratory experiments and complex, longer term, and large-scale natural energy and mineral systems. Well-designed field studies in key settings can span gaps in both temporal and spatial scales and improve predictive capacity for processes operating within Earth systems.

\section{A geothermal power plant at The Geysers near Santa Rosa, California.Photograph by Julie Donnelly-Nolan, USGS.}




\section{Goal 3: Provide Inventories and Assessments of Energy and Mineral Resources}

\section{Introduction}

Where will the United States obtain the energy and mineral commodities necessary to support its future infrastructure and technology? Policymakers, the global financial sector, industry, and others rely on the USGS to provide information needed for understanding the national and global distribution, supply, and demand for energy and mineral resources.

The USGS founding directive to examine the "... mineral resources, and products of national domain" (43 U.S.C. $\S 31$ ) includes fuel (coal, oil, uranium) and nonfuel mineral materials, as well as studies outside the national domain when such studies are in the national interest. The USGS is one of the principal Federal agencies that develop global information and comprehensive science for nonfuel minerals (fig. 8). The USGS provides energy resource assessments and shares responsibility for many aspects of global energy data and science with other Federal agencies, such as the Department of Energy (DOE), the Energy Information Administration (EIA), and the BOEM. Responsibility for managing fuel and nonfuel resources and the lands on which they occur belongs to other agencies. The USGS also plays a key role in assessing the energy and mineral resources endowment in other countries, as part of the larger U.S. effort to understand the global resources endowment, foster science diplomacy, and support investment, capacity building, development, and political stability in these countries while potentially increasing supply to the world market (National Research Council, 2012).

In the next decade, the need for resource estimates in an economic context will increase as stakeholders and decisionmakers seek information for considering multiple options at decision points along the resource lifecycle (U.S. Geological Survey, 2007). Analyses that model the interaction between geologic characteristics of the resource and engineering/economic cost variables provide an added dimension in terms of the amount of resource that potentially can be recovered and sold at a price covering the costs of discovery, development, production, and transportation to the market. Examples could include building on completed coal assessments to evaluate the effects of coal composition on its extraction and use and developing a full-cycle model to evaluate economic and other factors that affect the amount of undiscovered Arctic oil and gas resources that could be added to global supply. Extending the economic information in inventories and resource assessments provides additional data that may be useful to Federal, State, and other decisionmakers for understanding the potential benefits as well as environmental and other costs (goal 4). Depending on the scale and scope of innovation, iterative evaluations, new assessments (for newly significant elements or geographic regions, for example), or significant changes to assessment methodology may be required to adequately evaluate projected supply fluctuations (goal 5) and their effect.

\section{Energy}

The role of the USGS in evaluation of energy resources is focused on geologically based, undiscovered resources, exclusive of the U.S. Outer Continental Shelf. Periodic USGS assessments of technically recoverable, undiscovered oil, gas, and natural gas liquids in the United States and the world (Ahlbrandt and others, 2005) based on a systematic, vetted, probabilistic methodology are used by a wide variety of institutions around the world. The geologic reports (for example, U.S. Geological Survey Bighorn Basin Province Assessment Team, 2010) that accompany most domestic petroleum assessments are highly valued by customers and serve as long-lasting geoscience compilations for sedimentary basins across the United States.

As geologic understanding and extraction technologies advance, assessments must be updated, and assessment methodologies must evolve. The rapidly expanding production of oil and gas from low-porosity and permeability reservoirs (tight gas, shale gas, and shale oil) requires innovation in assessment methods as well as improved understanding of the geologic and geochemical nature of the reservoirs (goal 1). For example, a recent assessment (Coleman and others, 2011) of the undiscovered oil and gas potential of the Marcellus Shale (fig. 9) used production data from shale gas accumulations in this and other U.S. sedimentary basins to more effectively visualize and understand the long-term production profiles that characterize shale gas production through time. The geological and other information needed for underpinning these efforts can provide opportunities, such as Milici and others (2012), for leveraging and enhancing relationships with key USGS partners, including the State geological surveys.

The USGS also assesses domestic undiscovered resources of several nonpetroleum sources of energy. Undiscovered coal resources in the United States have been assessed, and reserve estimates are underway (for example, Scott and others, 2011). Uranium, currently (2013) the subject of an ongoing, joint USGS-EIA study of undiscovered resources, is hosted in a variety of geologic settings, which complicates the assessment process. An effort to develop a uranium environmental assessment methodology would complement the ongoing resource assessment effort and provide the scientific understanding of the influences of uranium resources and their potential effects on the environment. Likewise, renewed interest in thorium may necessitate additional study of the domestic potential for this resource (see Highlight, p. 22). Effective assessment methodologies for the commodity under consideration would benefit from an improved geologic understanding of occurrence (goal 1) and the evolution of extraction techniques and must portray the range of uncertainty of data and results at all stages of the assessment. 


\section{A. Energy}

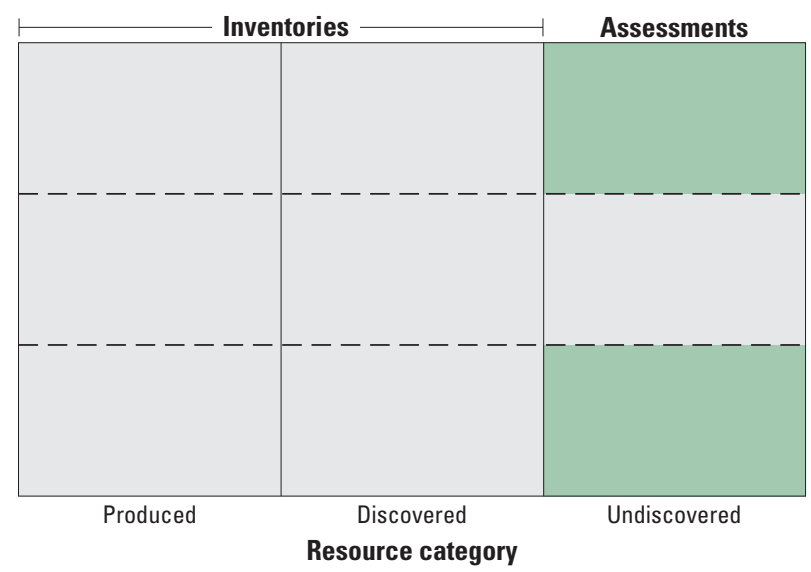

B. Minerals

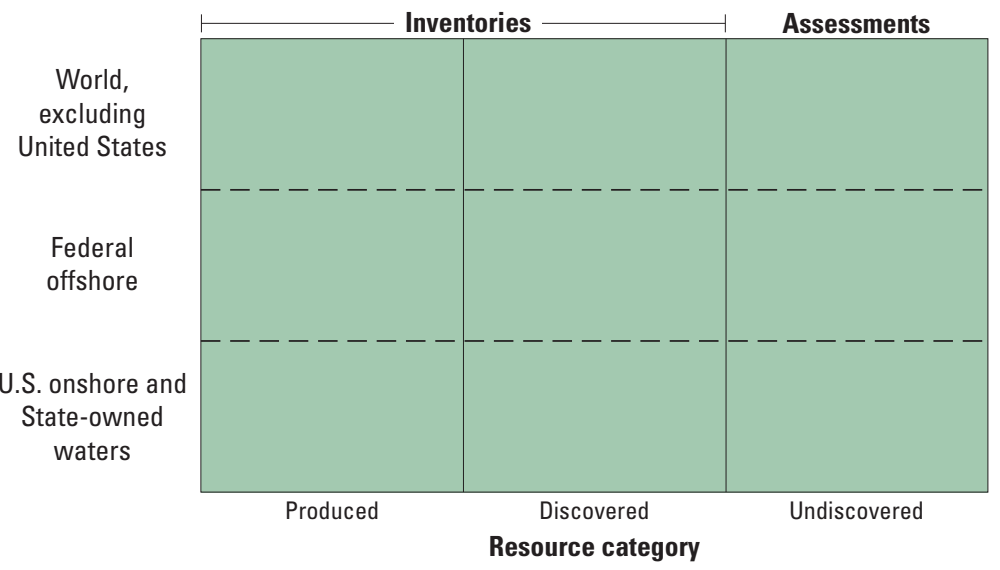

Figure 8. The U.S. Geological Survey (USGS) provides assessment and information (green areas) for $A$, energy resources, and $B$, mineral resources by geographic region and resource category. Discovered resources are those accumulations known to exist. Undiscovered resources are those theorized to exist, based on local geology being permissive for a specific type of energy or mineral deposit. For energy, the USGS conducts assessments of undiscovered resources. For nonfuel minerals, the USGS provides scientific data and inventories of produced and discovered resources as well as conducts assessments of undiscovered resources. The regulatory and resource stewardship responsibilities for these resources reside with other agencies.

\section{Major Questions}

- What are the undiscovered resources of technically recoverable oil, gas, coal, uranium, and geothermal energy in the United States and in the world?

- What is the range of economic and environmental consequences of extraction and delivery of these energy resources?

\section{Strategic Actions}

\section{3-1. Undiscovered Geologically Based Energy Resources}

- Action 3-1a.-Conduct periodic assessments of undiscovered, technically recoverable gas and oil resources of the United States (exclusive of the U.S. Outer Continental Shelf) and the world with increasing emphasis on reserve growth and unconventional resources, such as tight gas reservoirs.

- Action 3-1b.-Complete an updated national assessment of undiscovered uranium resources.

- Action 3-1c.-Conduct targeted assessments of emerging energy resources (for example, gas hydrates, geothermal energy, oil shale) as warranted by research findings (goal 1) and by advances in extraction technology.
- Action 3-1d.-Extend components of economic and environmental analyses, where possible in cooperation with other bureaus, to broaden the assessment of technically recoverable resources. The linking of these economic and environmental analyses with future integrated assessments, as described in goal 4, will enhance the utility and relevance of these analyses to resource stewardship agencies.

\section{Minerals}

The responsibility of the USGS for mineral materials includes evaluating the complete range of production data, reserves, resources, and undiscovered deposits (fig. 8) throughout the world and across the full spectrum of globally traded commodities. This responsibility requires a broad scope of USGS activities related to minerals, ranging from collection and compilation of geologic, production, and economic data to inventories of domestic and global reserves and resources, analyses of spatial and temporal patterns and materials flow, and assessments of undiscovered resources.

The USGS National Minerals Information Center (NMIC) collects, analyzes, and publishes data on domestic and global reserves. Domestic data collection activities are facilitated by cooperative agreements with State government agencies, whereas international minerals information is obtained annually by questionnaires and exchanges with organizations in approximately 100 countries. The USGS also tracks active mines, mineral operations, and facilities globally, and the Mineral Resources Data System (MRDS) provides limited geologic data for some domestic and global deposits, 


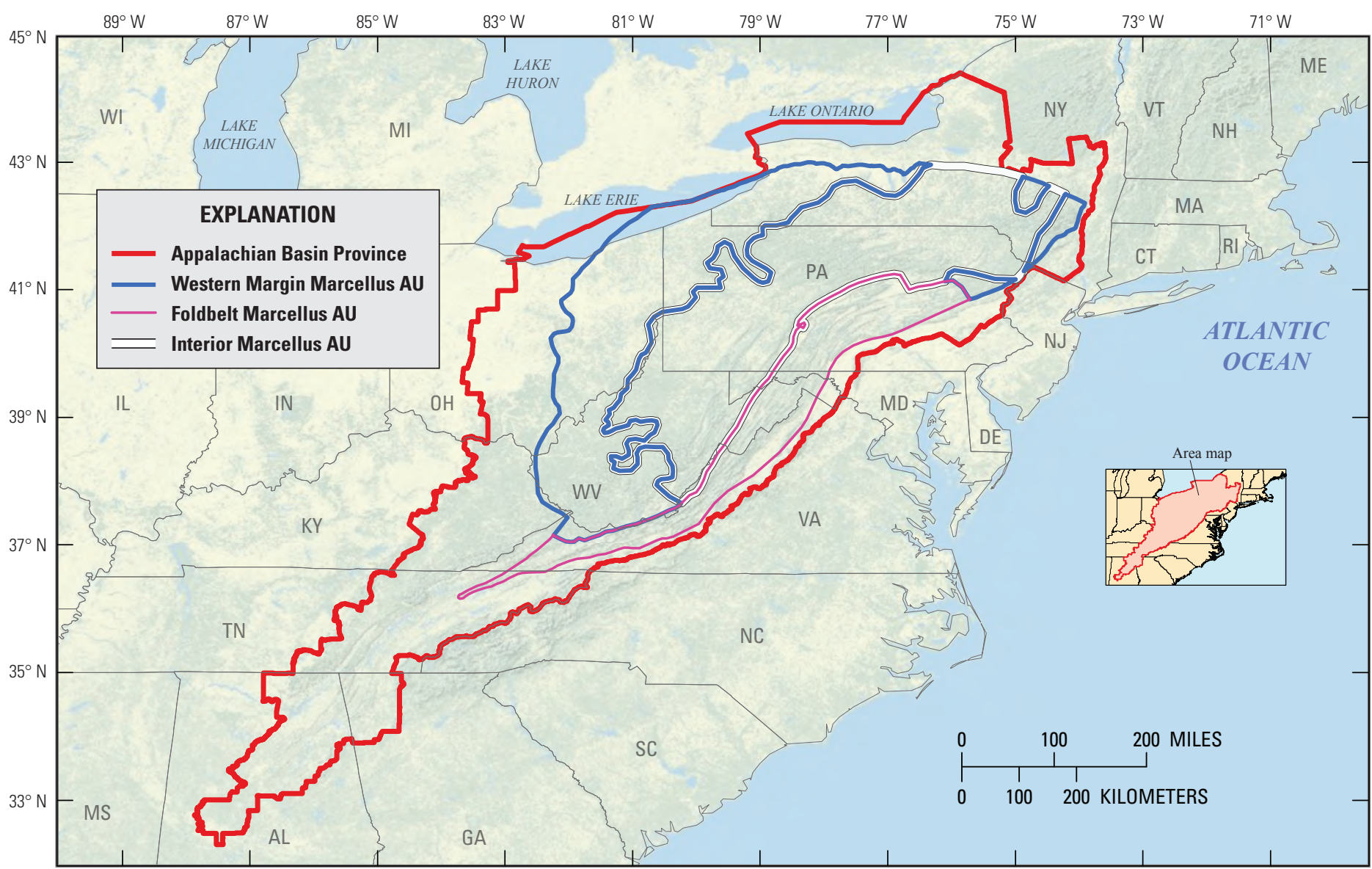

Figure 9. Extent of the Marcellus assessment units (AUs) within the Appalachian Basin geologic province. The Marcellus Shale is now exploited as a combination reservoir and source rock for natural gas and natural gas liquids. A probabilistic resource assessment completed by the U.S. Geological Survey in 2011 estimated a range of 43 trillion to 144 trillion cubic feet of undiscovered, technically recoverable gas (not counted as reserves), with a mean estimate of 84 trillion cubic feet. Most of the undiscovered gas is within the Interior Marcellus AU.

prospects, and mineral occurrences, but comprehensive and systematically updated coverage of discovered deposits worldwide is not currently (2013) available through the MRDS.

Public and private sectors rely on USGS minerals information to improve the understanding of how mineral materials are used within the economy and to forecast future supply and demand for these materials. This domestic and global information is subsequently used in the analysis of national and international policies, in formulating plans to deal with potential shortages and interruptions in mineral supplies, and in fostering the development of strategies for maintaining a competitive position within the global economy.

Assessments of domestic undiscovered mineral resources are amenable to probabilistic methodologies similar to those used for energy resources, but mineral resources occur in a broader range of geologic settings and require an understanding of a much wider array of geologic frameworks. With this additional knowledge and more expansive study of the geochemistry of Earth systems (goal 1), more accurate geologic models of mineral resources can be built and used to constrain estimates of the location, quality, and quantity of undiscovered resources.

\section{Major Questions}

-What are the global reserves and annual production of nonfuel mineral materials, and what potential supply restrictions do these indicate?

- What are the discovered and potential undiscovered resources of nonfuel minerals in the United States that could bolster future supplies?

- What types of information are needed to provide unbiased assessments of undiscovered mineral resources and effectively portray their uncertainty, and at what scales? 


\section{Strategic Actions}

\section{3-2. Discovered Nonfuel Mineral Resources}

- Action 3-2a.-Expand partnerships with governments, industry, and the Nation's research and development sectors to ensure that the USGS has timely, accurate, long-term, and comprehensive global commodity data for all nonfuel mineral commodities.

- Action 3-2b.-Establish a periodic review, in consultation with government and industry partners, of the range of commodities covered, process and scope of data collection, and the format, range, and availability of data products.

- Action 3-2c.-Expand due-diligence field studies to confirm the geologic characteristics and the resource and grade data for high-priority commodities. Work could include the tracking of reserve-growth characteristics of individual mineral deposit types.

- Action 3-2d.-Enhance the scope and functionality of the domestic discovered resources database. This spatially oriented, continuously updated national reference system ideally would contain geologic, production, reserve, and resource data for all mines, prospects, and mineral occurrences within the United States.
- Action 3-2e.- Strengthen and expand the analytical functions of the NMIC to provide more comprehensive overviews of changes to global nonfuel mineral supply and demand. In particular, expand spatially oriented analyses of global production, trade, manufacturing, and materials end-use.

\section{3-3. Undiscovered Nonfuel Mineral Resources}

- Action 3-3a.-Reevaluate the methodology, scale, scope, coverage, and output of undiscovered mineral resource assessments. Include consideration of base data, engineering (technology, processing), environmental, and mineral economics expertise in assessments and evaluate the uncertainty and effectiveness of qualitative and quantitative (probabilistic) methodologies.

- Action 3-3b.-Develop methodologies for assessment of undiscovered nonfuel mineral resources in frontier regions: in Alaska, the EEZ, and the ECS and for resources deeper than $1 \mathrm{~km}$ below the Earth's surface. This activity would benefit from appropriate strong partners, including the BOEM, in the offshore realm.

Supporting infrastructure (foreground) and mining operations at the Red Dog ore deposit (background), the world's largest producer of zinc, located in the western Brooks Range in Alaska. In addition to discovered resources at Red Dog, there may be undiscovered resource potential in the region as we learn more about the complex structural and fluid-flow history in this geologic setting. Mineral resource assessments that incorporate geologic framework studies are used to estimate the probability of undiscovered deposits in Alaska and elsewhere that may contribute to future mineral supplies. Photograph by Tom Moore, USGS. 


\section{Thorium: Why and Where?}

Globally, thorium is experiencing much renewed interest and research investment as a potential fuel source because it provides a source of nuclear power that does not proliferate weapons-caliber plutonium, has the potential to generate electrical power with a low carbon footprint, and may have operational advantages compared with uranium-fueled reactors in terms of power density, cost, scale, and waste disposal. Major research and development efforts on thorium-based reactors are underway in China and India. U.S. research on thorium and molten-salt nuclear reactors was discontinued in 1969, but recent national energy policy discussions have renewed calls for research and development of thorium as an energy resource.

Geochemically, thorium and rare earth elements (REEs) coexist. The radioactivity of REE deposits is principally owing to thorium, which presents an environmental issue in the waste streams of REE mining and processing. Within the United States, thorium could be produced as a byproduct from the production of REEs, thereby converting a once undesirable waste into a valuable commodity.

The United States has some of the largest thorium resources in the world. The USGS led a considerable amount of research on thorium geology (fig. 10; Van Gosen and others, 2009) from the late 1950s to the late 1980s. Many thoriumbearing districts in the United States were studied, described, mapped, and sampled (Van Gosen and others, 2009). More than 200 thorium-rich veins in the Beaverhead Mountains form the Lemhi Pass district, which is thought to contain the largest concentration of thorium resources in the United States and is the site of renewed thorium exploration activity. Given the growing interest in thorium, an improved understanding of the geology, mineralogy, geochemistry, and resource potential of thorium-bearing systems could provide information needed for the development of comprehensive energy policies and consideration of alternatives during the next decade.

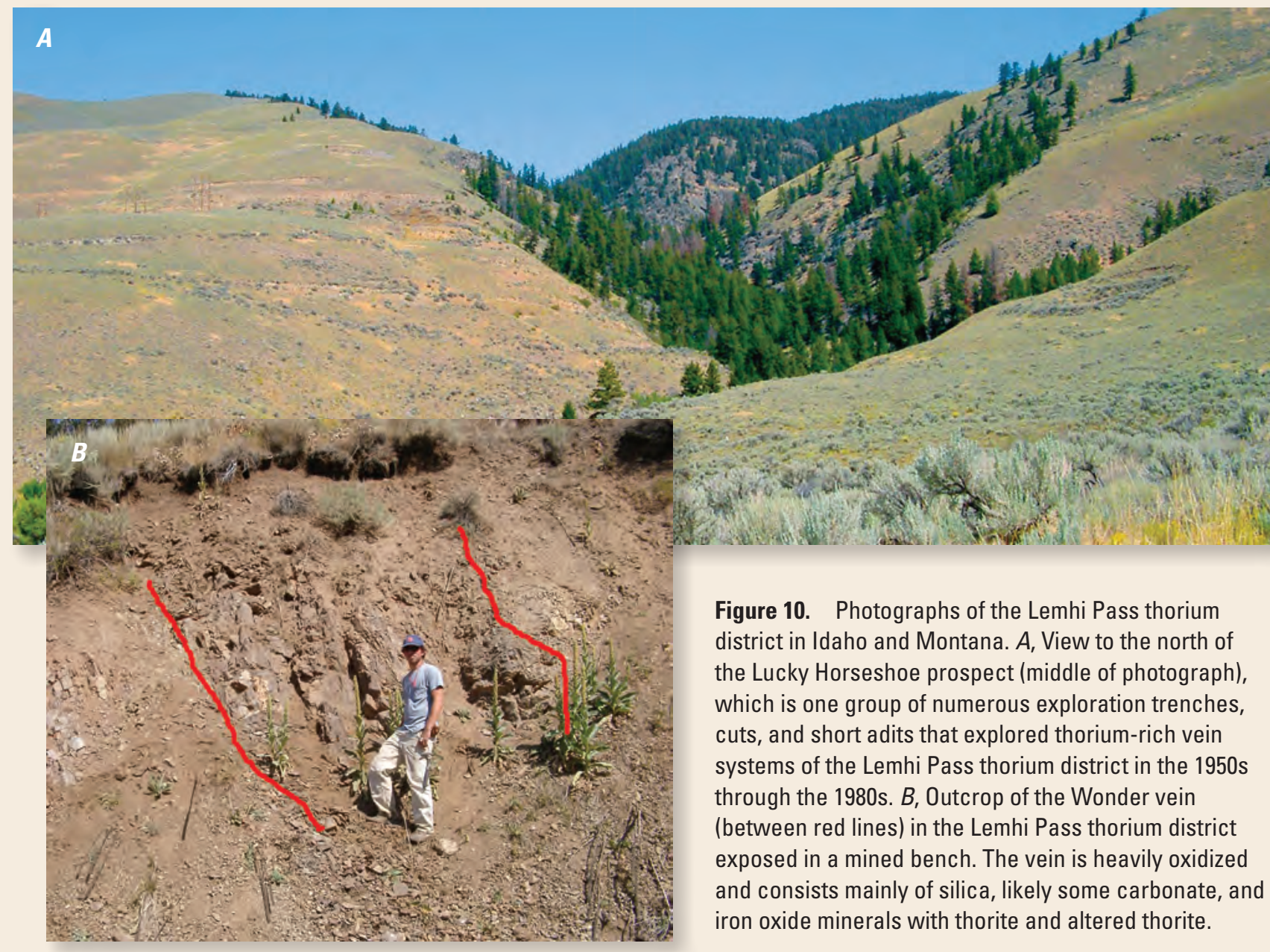




\section{Goal 4: Understand the Effects of Energy and Mineral Development on Natural Resources and Society}

\section{Introduction}

Policymakers and resource stewards will face challenges through the next decade in terms of making decisions amidst uncertainty, particularly in emerging areas where information is lacking or the state of science is equivocal (National Research Council, 2005). Increasing domestic energy and mineral production, emerging use of new technologies and renewable energy development, and mandates to consider the costs, benefits, and cumulative effects of development present complex challenges for agencies responsible for managing natural resources in the United States. Refinements in directional drilling and hydraulic fracturing to produce unconventional hydrocarbon resources have increased accessibility of these resources, but these techniques have potential subsurface and above-ground effects on water and other resources that are only partially understood. Similarly, the importance of reducing greenhouse gas emissions has contributed to the growth in the use of renewable energy sources (Intergovernmental Panel on Climate Change, 2011), such as wind and solar, but the linkages of renewable energy infrastructure to mineral development and the environmental effects of using these energy resources merit further study. Information about these benefits and trade-offs can lead to better decisions culminating in responsible development of resources, ecosystem protection, and overall benefits to society (National Research Council, 2005).

The overarching approach of this goal is to develop the energy and mineral data, frameworks, analytical methods, and products to support the information needs of decisionmakers who must "accommodate ecosystem-based management practices as they face competing demands for recreation, transport, leasing, conservation, and economic growth" (U.S. Geological Survey, 2007, p. 26). The need for more holistic approaches to characterize societal value in the context of decisions gives rise to the concept of ecosystem services. The understanding of ecosystem services, which are broadly considered to consist of the results of ecosystem processes that confer benefits on human society (President's Council of Advisors on Science and Technology, 2011), requires integrated applications of economics and ecology (National Research Council, 2005).

Such applications could be used to support information needs for decisions faced at various stages during the energy and mineral resources lifecycle. One effort might consist of an evaluation of ecosystem services of the landscape before development. Policy and resource management decisions frequently imply changes relative to some baseline, and most changes imply trade-offs, that is, more of one good or service but less of another (National Research Council, 2005); hence there is an inherent value in understanding baseline conditions in a predevelopment setting. Key first steps in this approach are designating liaisons to work with land and resource managers to better understand their needs and developing new targeted spatial products based on existing data and knowledge.

Recognizing the need for more comprehensive information for decisions, State, Federal, and nongovernmental organizations are increasingly interested in broader assessment, inventory, and research activities, especially for sizeable geographic areas. Large landscape initiatives - for example, DOI landscape conservation cooperatives, Bureau of Land Magement (BLM) rapid ecoregional assessments, National Park Service vulnerability assessments, and the Western Governors Association wildlife corridors initiative - are providing information at requisite spatial scales suitable for regional or cumulative effects analyses. These initiatives will benefit from additional research and technical assistance, but meeting these needs requires application of the research and foundational understanding developed through goals 1 and 2, the reliable inventory products discussed in goal 3 , and strong integration of research capabilities within USGS and with external partners. Achieving this goal will require scientific collaboration and the dedication of resources to support the evolving adaptive management strategies developed by the DOI (Williams and others, 2009) and other users of USGS assessment products.

An integrated assessment (see Highlight, p. 25) brings together disparate datasets in a common format so they can be examined and used to support broader policy and decisionmaking processes. Integrated assessment also provides an organizing framework for analysis and communication that is adaptable to the scope and complexity of the question or issue and can comply with parallel legal requirements for Federal land management and planning (for example, environmental impact statements).

The common characteristics of integrated assessment include collaboration between policymakers or managers and scientists, consideration of multiple resource values and societal needs, and development of relevant products based on the best available information and analytical methods. Integrated assessments that include information on energy and mineral resources, other natural resources, and socioeconomic considerations represent interdisciplinary endeavors that leverage expertise across the USGS and elsewhere (see Highlight, p. 26). USGS research on fundamental Earth processes, interactions between energy and mineral resources and the environment, and quantitative assessments of the distribution and abundance of resources (goals 1-3) form an essential scientific and technical foundation for integrated assessments. Improved scientific understanding and information on ecosystems, water resources, land use, and climate change could be developed through focused work across the USGS. Using multidisciplinary teams, the USGS can provide information (goal 2) on different classes or specific types of energy and mineral resources, such as uranium, wind energy, or coal, to inform decisions and national energy policy questions that arise at multiple scales to meet the needs of decisionmakers. 


\section{Major Questions}

- What science can the USGS provide to help assess the range of effects of energy and mineral development relative to other natural resources and socioeconomic considerations to facilitate responsible development?

- How can USGS science help stakeholders and decisionmakers characterize and evaluate tradeoffs among renewable, fossil, and nuclear energy resources, taking into account the full lifecycle of resource development, use, and disposal?

- What data and information are needed by other Federal and State agencies and public resource decisionmakers to implement best practices throughout the lifecycle of energy or mineral resource development?

\section{Strategic Actions}

\section{4-1. Spatial Analysis of Energy and Mineral Resources Occurrence and Development}

- Action 4-1a.-Designate liaisons and a network of energy and mineral resources experts within the USGS who work with land and resource managers, including those from DOI bureaus and State agencies, to identify important information needs.

- Action 4-1b.-Provide information on energy and mineral development potential to large landscape conservation initiatives that are evaluating such development with respect to other natural resources and socioeconomic considerations.

- Action 4-1c.-Develop new nationwide spatial data products for energy and mineral resources. This activity could be coordinated with other agencies, as appropriate, to leverage use of existing datasets. These products could include existing areas of development for these resources and associated infrastructure, such as roads, pads, pipelines, ponds, compressor stations, and other facilities associated with resource development.

Freeport McMoRan Copper \& Gold, Inc.'s Safford Mine (copper) in the foothills of the Gila Mountains (snow capped in the background) north of Safford, Arizona, 2012. For scale, note the haul truck. Photograph by Bruce Gungle, USGS.

\section{4-2. Exploring Interdisciplinary Approaches for Assessing} Effects of Energy and Mineral Development

- Action 4-2a.-Identify metrics or indicators that reflect the economic and environmental effects and uncertainty of energy and mineral development on other natural resources. For example, a method for evaluating water use and production associated with unconventional oil and gas resource development could improve the understanding of the potential effects of development on the availability and quality of water resources.

- Action 4-2b.-Develop and refine methods for incorporating social, cultural, economic, and ecosystem service metrics into integrated assessment approaches through collaboration with partners and stakeholders.

- Action 4-2c.-Develop methods to estimate potential land surface and seabed disturbance associated with potential development. These methods could draw on knowledge of the resource, including expanded use of USGS estimated ultimate recovery information for oil and gas resources, as well as requirements for development.

- Action 4-2d.-Assess the effects of renewable energy development on other natural resources and society, in coordination with resource stewardship agencies. This activity could include evaluations of the following: physical and biological components of ecosystems, models and assumptions about development effects at different resource lifecycle stages, and the effectiveness of mitigation strategies.

- Action 4-2e.-Develop decision analysis and support tools to address stewardship needs. Examples of such recognized needs include BLM work processes, such as inventory and assessment, planning, permitting and managing uses, evaluating best management practices for mitigation and reclamation, and monitoring. 


\section{Uranium in the Grand Canyon: A Case Study in Integrated Research and Assessment}

Issues involving legacy environmental effects, such as those caused by historical mining activities, could challenge the availability of uranium for energy production by resulting in increased environmental costs, societal resistance to uranium mining, or restrictions on accessibility. For example, about one million acres of Federal land in the Grand Canyon region of Arizona (fig. 11) was temporarily withdrawn from new mining claims in July 2009 by the Secretary of the Interior because of concerns that uranium mining could have negative effects on the land, water, people, and wildlife.

As directed by the Secretary of the Interior, the Bureau of Land Management engaged the USGS to assist in evaluating the effects of withdrawing these lands from new mining claims. The USGS led multidisciplinary studies that provided estimates of uranium resources, examined the effects of previous breccia-pipe mining, summarized water-chemistry data for streams and springs, and investigated potential biological pathways of exposure to uranium and associated contaminants (Alpine, 2010). An integrated approach (fig. 12) and careful planning were needed to integrate data from various components of uranium lifecycle research across mission areas and to package data so that they could be used in an integrated assessment by social scientists and economists to assess alternative scenarios and thereby help decisionmakers weigh the tradeoffs of uranium mining in the Grand Canyon area. Working together, these USGS groups led a study that could become a model for integrated USGS studies in the future.
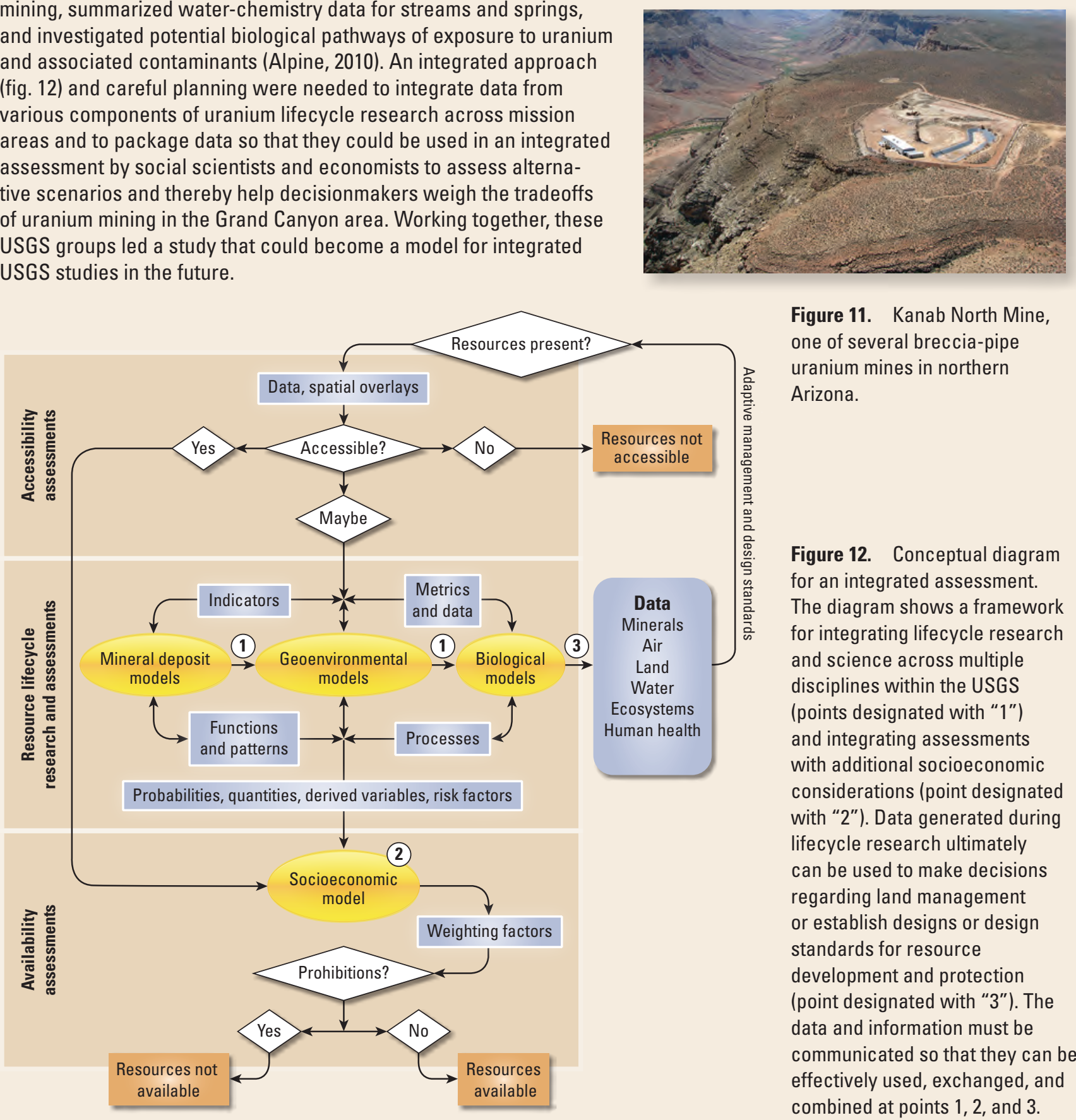

Figure 11. Kanab North Mine, one of several breccia-pipe uranium mines in northern Arizona.

Figure 12. Conceptual diagram for an integrated assessment. The diagram shows a framework for integrating lifecycle research and science across multiple disciplines within the USGS (points designated with "1") and integrating assessments with additional socioeconomic considerations (point designated with "2"). Data generated during lifecycle research ultimately can be used to make decisions regarding land management or establish designs or design standards for resource development and protection (point designated with " 3 "). The data and information must be communicated so that they can be effectively used, exchanged, and combined at points 1,2 , and 3 . 


\section{Integrated Assessment for Southwestern Wyoming}

Driven by local and regional leaders, the Wyoming Landscape Conservation Initiative (WLCI) was officially launched in 2007 with support from the U.S. Department of the Interior. The WLCI mission is to implement a long-term, science-based program for assessing, conserving, and enhancing fish and wildlife habitats while facilitating responsible energy and other development through local collaboration and partnerships. Partners in the WLCI include the Bureau of Land Management, the USGS, the U.S. Fish and Wildlife Service, the Wyoming Game and Fish Commission, the Wyoming Department of Agriculture, the U.S. Forest Service, six Wyoming county commissions, nine of Wyoming's conservation districts, and the Pinedale Anticline Project Office.

The role of the USGS is to provide multidisciplinary scientific and technical assistance support to WLCI partners and to advance the overall scientific understanding of ecosystems in the southwestern Wyoming landscape. Working with WLCI partners, the USGS has developed an integrated assessment for southwestern Wyoming (fig. 13; Wyoming Landscape Conservation Initiative, undated). The integrated assessment is an analysis of WLCI resources based on best available data and information and includes roads, energy development, mines, and urban areas along with aquatic and terrestrial natural resources and priority management areas designated by partners. Information is summarized by watershed using a transparent and hierarchical approach that facilitates understanding of multiple resources and their contribution to summary index scores. The integrated assessment provides a support tool for landscape-scale conservation planning and evaluation and a data and analysis resource for addressing specific agency management questions.

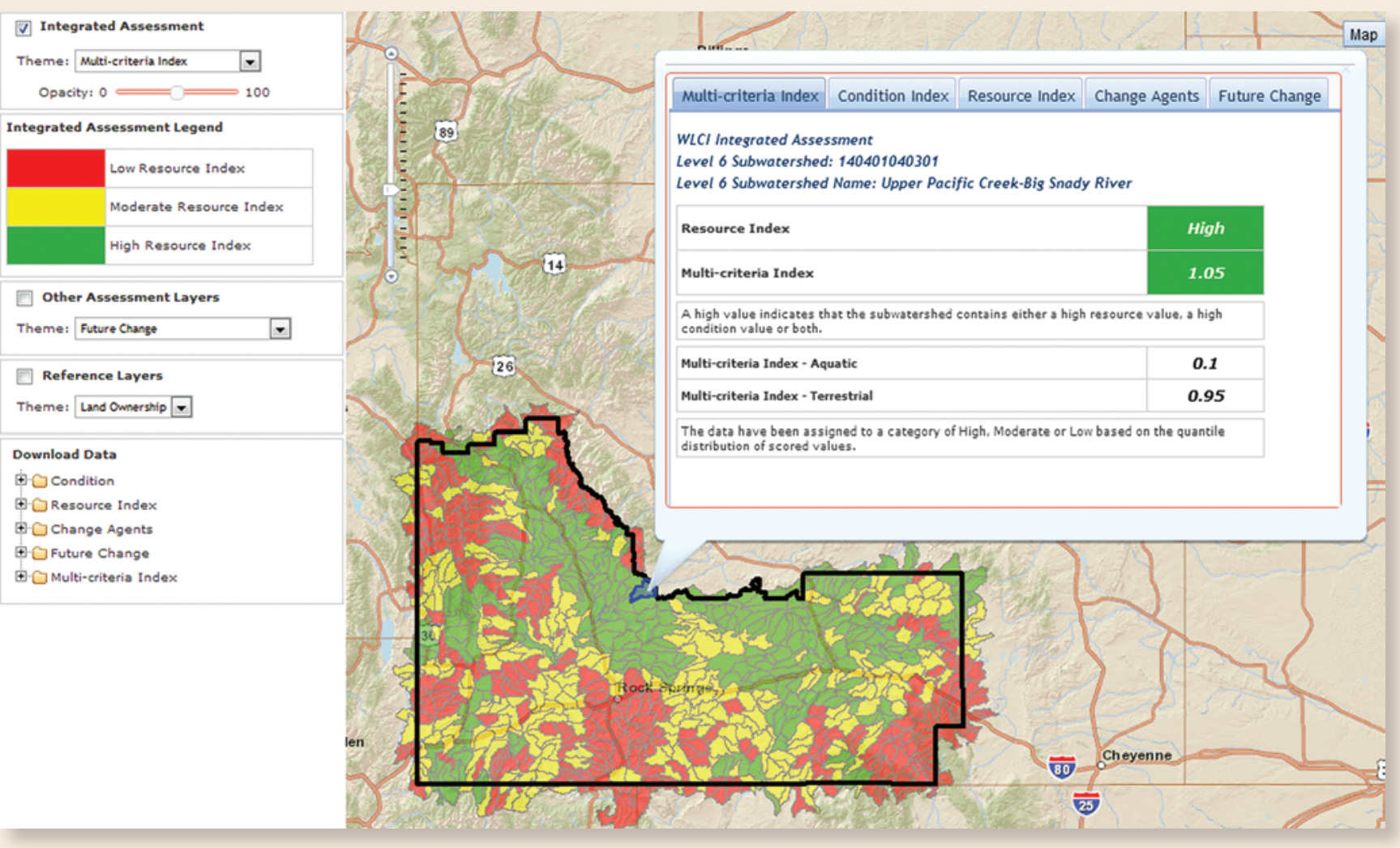

Figure 13. The Wyoming Landscape Conservation Initiative integrated assessment Web interface. Information on key resources is summarized by watershed, and data used in the development of the assessment are available for download and further analysis. 


\section{Goal 5: Understand the Reliability and Availability of Energy and Mineral Supplies}

\section{Introduction}

Challenges to national security, economic vitality, quality of life, and environmental well-being can arise suddenly and catastrophically or as a result of long-term trends. Therefore, our scientific enterprise must remain responsive and adaptable to meet new and evolving challenges. The human drivers of change are complex and diverse, including advances in technology, competition for natural resources, evolution of national and international policies and conflicts, land-use change, effects on ecosystems, and shifting social mores and attitudes. Climate change and natural and anthropogenic disasters and emergencies also can affect energy and minerals resource supplies. Some of these events may trigger perturbations in the immediate reliability of energy and mineral supplies as well as create environmental stewardship consequences. Conversely, other events might affect the availability of resource supplies, that is, our Nation's ability to obtain resources over the longer term (years to decades) (National Research Council, 2008).

The USGS provides information that is essential underpinning for policy, management, and stewardship decisions on resource extraction, use, regulation, and waste management, but the magnitude and speed of world events and societal changes are placing a premium on flexibility and foresightedness. We emphasize in this section the application and adaptation of existing USGS expertise to address the future of energy and mineral supplies for the Nation.

\section{Major Questions}

- How might the emergence of new technologies or patterns of resource use affect the mineral and energy requirements of the Nation, and what science and information are needed to meet these national requirements?

- What approaches can be used to identify vulnerabilities within the supply chain of mineral materials?

- How can the USGS better prioritize and align energy and minerals research activities to address the most critical future issues?

\section{5-1. Sudden Disruptions Affect Supplies}

Some future events will arrive suddenly with little warning and will require immediate responses that make the best use of existing information and capabilities. Disaster response precipitated by natural hazards, such as earthquakes, tsunamis (see Highlight, p. 29), and floods, by terrorist acts, or by catastrophic human error requires the ability to provide relevant information almost instantaneously.
The ability of the USGS to respond rapidly and effectively to unforeseen disasters with energy and mineral resources expertise is dependent on leveraging a suite of existing geological, geochemical, geophysical, and mineral economics expertise and analytical capabilities. Within the past decade, the USGS has responded to manmade disasters by providing remote sensing to environmentally map the World Trade Center (WTC) area with imaging spectroscopy (Clark and others, 2006) and chemical characterization of dusts generated by the WTC collapse (Plumlee and Ziegler, 2003); chemical measurements before and after wildfires to assess changes to soils and waters (Eppinger, 2002; Eppinger and others, 2003; Wolf and others, 2010); inorganic, organic, and microbial characterization of flood sediments immediately following Hurricane Katrina (Plumlee and others, 2006); and volume and flow rate measurements of oil from the Deepwater Horizon oil spill (Labson and others, 2010). Efforts such as these are important to characterizing the initial effects from catastrophic events and providing the foundational knowledge for informing damage assessment and recovery efforts.

In terms of anticipating and preparing for future events, USGS expertise and information can be used to underpin the development of scenarios and help inform response planning and recovery efforts. As one example, the southern California ShakeOut scenario (Jones and others, 2008) was the basis for a cooperative project to evaluate the physical, social, and economic consequences of a modeled large earthquake. A magnitude 7.8 earthquake as described in the ShakeOut Scenario would cause significant damage to buildings and infrastructure. Langer (2011) estimated that more than six million metric tons of newly mined aggregate would be needed for emergency repairs and for reconstruction within the study area in the five years following the event. This information is important for understanding both the potential magnitude and the duration of this perturbation on regional aggregate supplies. Greater emphasis on this type of study exemplifies the kind of research directions anticipated by this goal. To support these endeavors, additional investments would be needed to establish mechanisms for timely sample and data analysis, interpretation, and delivery to the responders, decisionmakers, and the general public in understandable formats.

\section{5-2. Evolving Issues Affect Long-Term Availability}

Two factors that will continue to significantly affect global demand for energy resources and mineral materials in the next decade are the rapid economic development that several countries are experiencing and the proliferation of new or emerging technologies. The expected increase in global demand, especially in countries undergoing rapid economic development, is, in part, a reflection of the need to build a modern infrastructure. For example, China has accounted for most of the global increase in mineral consumption from 2000 to 2010. Global mineral consumption is expected to increase in response to further development in China and economic 
development in countries with large populations, such as India.

The use of new technologies represents another factor that changes mineral consumption rates and patterns. The influence of these technologies on engineering design is steering a significant shift in consumption of high-technology materials (for example, aluminum alloys, doped crystals and films, carbon-composite fibers) and associated fuels (for example, high-octane fuels), all produced with different forms of metals and mineral materials. This rapid evolution in consumption patterns highlights the limits of our knowledge about the distribution and concentration of some of the raw materials that these industries use.

To respond to issues of energy and mineral supplies, the USGS must understand the availability of energy and mineral materials at both national and global scales. For instance, constraining imports of these resources have the potential to affect U.S. economic development and national security, thus information on global and domestic resource distribution and availability can inform decisions about risks associated with import dependence and possible actions to mitigate supply risk (National Research Council, 2012).

As the Nation's energy mix changes, the USGS will likely expand its research and assessment portfolio to include a more comprehensive suite of energy resources, including hydrocarbon- and nonhydrocarbon-based sources (U.S. Geological Survey, 2007, p. 25), and expand studies that provide a geological basis for energy mix analyses, such as the age and decline rates of giant domestic fields from which a large proportion of oil supply is produced. Another topic could be the geological understanding of resource volume and distribution, such as analysis of stranded gas (Attanasi and Freeman, 2011), particularly in areas likely to emerge as the focus of significant future development. In aggregate, these activities could be used to provide a foundation for developing energy mix scenarios, for identifying new avenues of geologic processes research, and for refining approaches to resource assessments.

Many mineral commodities are increasingly important for clean-energy industries, defense applications, and consumer electronics. A geographic concentration in global supply for some of these energy-critical elements (American Physical Society and Materials Research Society, 2011) introduces issues of supply risk. The minerals necessary for these emerging technologies need to be a key component of the USGS portfolio of minerals research and information collection activities. Further development of materials flow and supply chain analyses (see Highlight, p. 30) are needed to better understand the movement of materials and their derivatives through the global economy and facilitate analyses of supply risk.

The methodologies for analyzing the materials flow of energy and mineral materials are just evolving, yet their development is fundamental to understanding how natural and human systems interact with and influence global economies. The depth and consistency of USGS databases on mineral statistics and mineral resources are vital components in building viable models for minerals and mineral materials. USGS data on materials flows, in combination with energyflow information from partners such as the EIA, can be used to model the energy and minerals requirements for new or emerging materials technologies, as well as monitor supply fluctuations, assess energy and material demands for different industry sectors, provide warnings of potential supply risks, and illuminate vulnerabilities in global production and manufacturing supply chains.

The output of these models could provide a platform for comprehensive planning and management of national resources and for identifying short- and long-term vulnerabilities in the supply chain of minerals critical to the national economy and defense. Supply chains and end uses of mineral materials are dynamic; hence, the suite of materials identified as strategic or critical are also dynamic and will require periodic reevaluation. Materials flow analyses and network models may also provide an active, quantifiable mechanism to help inform decisions on future USGS energy and minerals research activities.

\section{Strategic Actions}

\section{5-1. Sudden Disruptions Affect Supplies}

- Action 5-1a.-Enhance capabilities for rapidly responding to events, such as natural disasters or manmade disruptions, that result in significant perturbations to resource supplies or the release of energy resources or mineral materials to the environment. Enhancing these capabilities would require strengthening of coordination mechanisms to facilitate deployment of rapid-response science teams and equipment to collect time-sensitive data from the field and to extract scale-appropriate data or other information from existing databases (see Highlight, p. 29).

- Action 5-1b.-Conduct research on how technological and economic systems interact to affect energy and minerals availability, and develop scenarios to describe how perturbations influence that dynamic. Such analysis and reporting could specifically focus on nodes and links in supply chains that are particularly vulnerable to sudden disruption.

\section{5-2. Evolving Issues Affect Long-Term Availability}

- Action 5-2a.-Develop approaches for identifying mineral materials that are strategic and critical to the U.S. economy, energy supply, infrastructure, and national security. This activity would benefit from consultation with partners, such as the U.S. Department of Defense, industrial manufacturers, the National 


\section{USGS Scientific Contributions to Disaster Response Following the 2011 Japan Earthquake} and Tsunami

The devastating, magnitude 9.0 earthquake and subsequent tsunami that struck the eastern coast of Japan near Tohoku on March 11, 2011, required coordinated disaster response efforts, including significant science contributions. With at least 15,000 people killed and hundreds of thousands displaced from their homes, the humanitarian efforts were paramount, but determining the full effect of the disaster also involved assessing the local and global physical and economic effects. In addition to the damage to the nuclear reactors at Fukushima, there was widespread damage to the area's industry and infrastructure. The USGS analyzed the effect of the earthquake and tsunami on mineral facilities in the region to assess potential disruptions to Japanese and global mineral and material supply chains (fig. 14; Menzie and others, 2011). Nine cement plants in the affected area produced 30 percent of Japan's cement; eight iodine plants in the same region accounted for 25 percent of the world's iodine supply. The earthquakeaffected zone also included nine metal refineries, four iron and steel plants, four limestone mines, and two titanium facilities.

The USGS briefed policymakers soon after the quake and published a report on the findings within eight business days of the event (Menzie and others, 2011). This type of rapid data analysis immediately following a disaster is of major importance for response planning by governments and industry. As a result of the Tohoku effort, USGS minerals information and analyses are now being incorporated into disaster-planning scenarios, such as the U.S. regional ShakeOut earthquake exercises.

Figure 14. Locations of mines and mineral facilities in Japan.

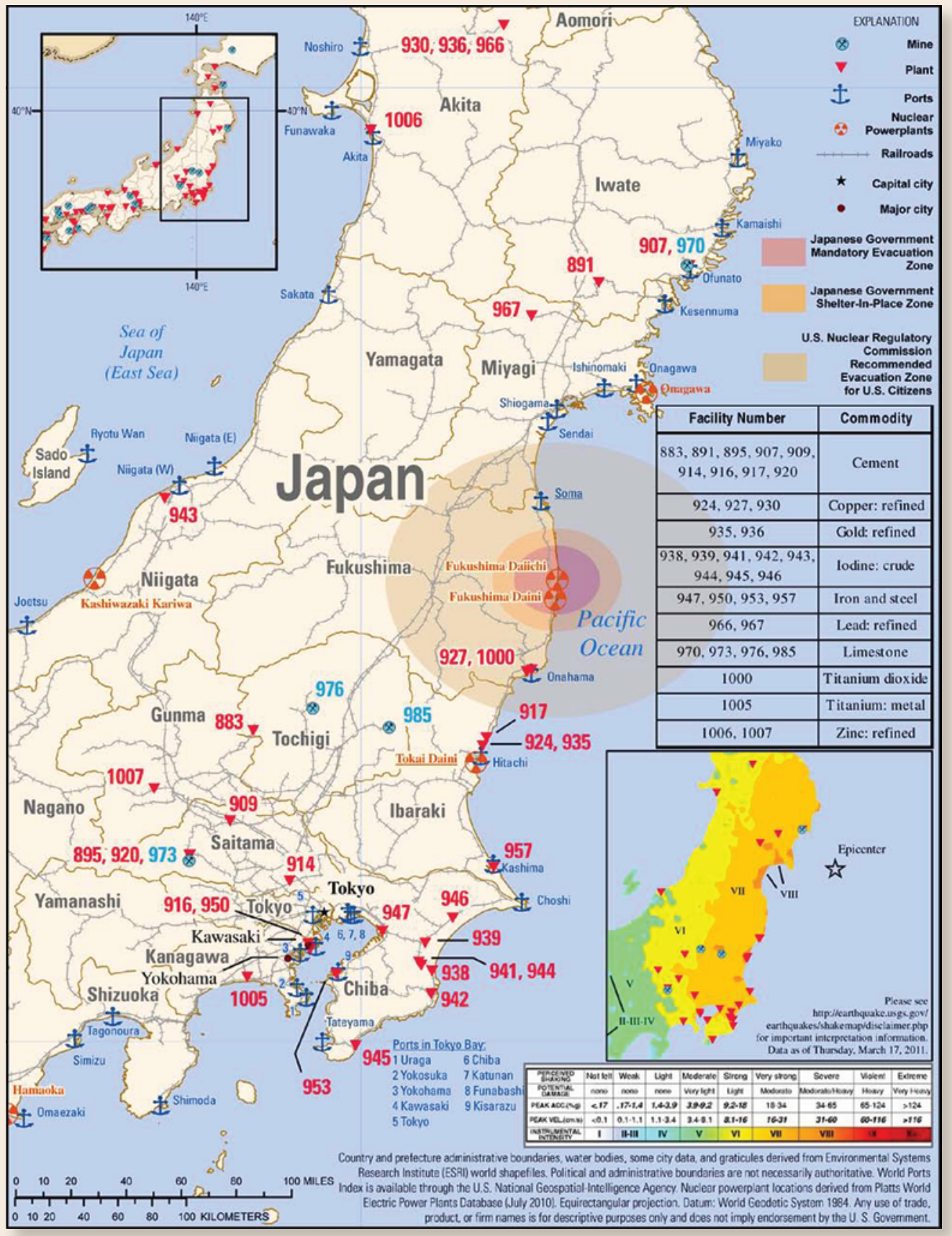




\section{Materials Flow Analysis: Illustrating Global Commodity Supply Vulnerabilities}

Materials flow analysis (fig.15A; modified from Kostick, 1996) is the systematic accounting of a material or commodity from extraction through processing, manufacturing, reuse, and ultimate disposal (Brown and others, 2000; National Research Council, 2004). The USGS National Minerals Information Center provides information on the demand for minerals and mineral materials across industry sectors and develops materials flow analyses for selected commodities (fig. 15B; data from Lori Apodaca, U.S. Geological Survey, written commun., April 4, 2012). This example (fig. 15B) highlights a derivative application of materials flow analysis: the ability to evaluate human influences on global biogeochemical cycling of elements, such as sulfur; data are reported in million metric tons (Mt).

Supply-chain analysis, a more comprehensive form of materials flow analysis, illustrates each step in the chain of use from source to disposal. Supply-chain analysis accounts for all steps of production and processing (mines, mills, smelters, refineries, fabricators, and the manufacture of final goods), inventories and stockpiles, costs (fixed, variable, and new capacity startup), and necessary transportation facilities. Fully developed models require extensive data on the economics of production and trade, values of processed materials, demand variations through time, knowledge of materials properties specific to individual sectors of the economy, information on the capacity and manufacturing capabilities, and location for all downstream infrastructure (processing and production facilities). An analysis of supply chains for materials critical to the United States is required to identify economic vulnerabilities that could be precipitated by global trends and circumstances. The USGS is uniquely positioned to develop these tools.

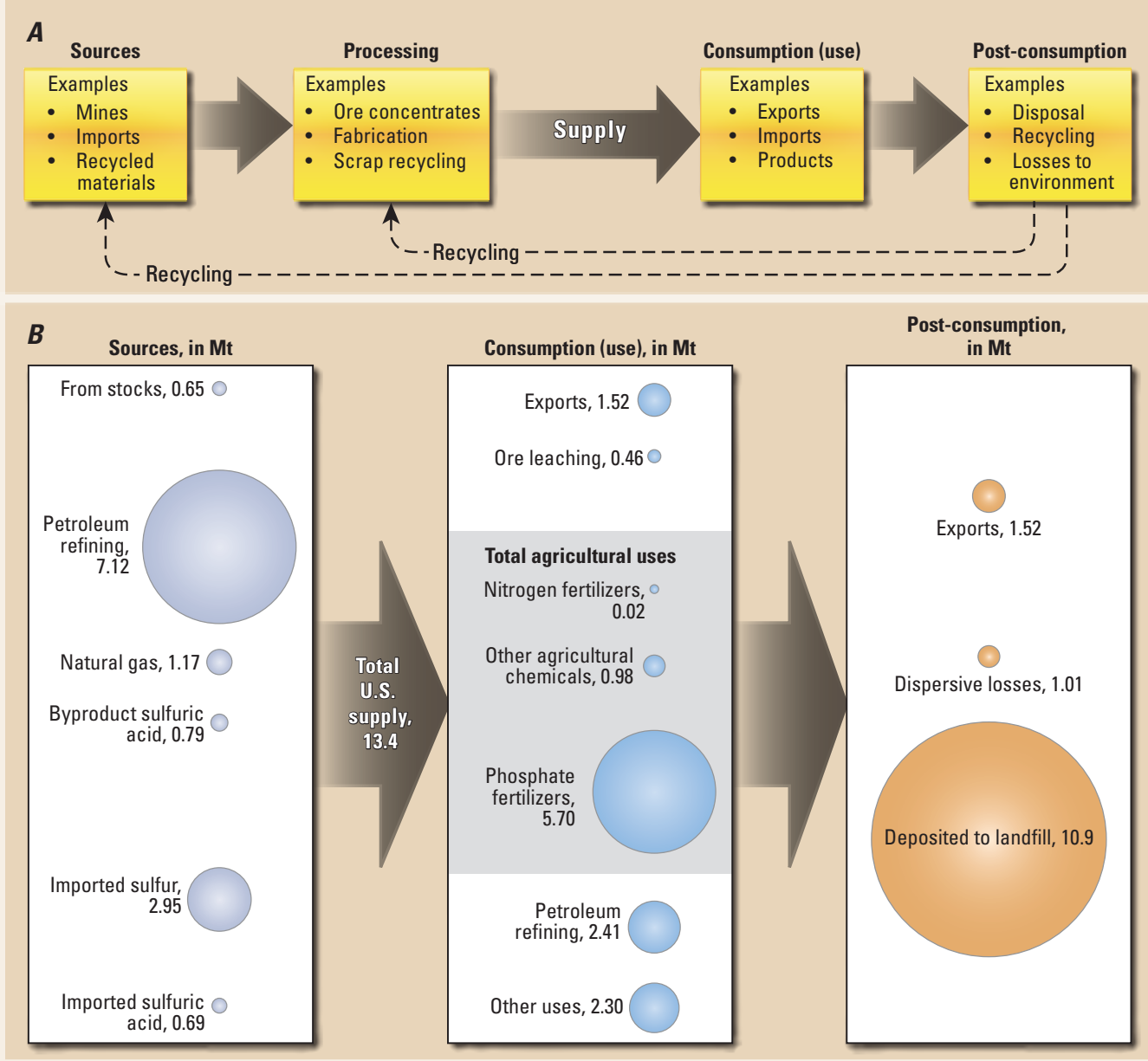

Figure 15. Diagrams showing materials flow models. $A$, Conceptual framework for a material supply model. $B$, Example flow model for sulfur in the United States. 
Institute of Standards and Technology, the DOE, and the Office of Science and Technology Policy.

- Action 5-2b.-Conduct targeted studies on the global flow of a select number of critical mineral materials as identified in action 5-2a. Global materials flow analyses can be used to identify vulnerabilities in supply chain nodes caused by human and natural events and knowledge gaps in our understanding of supply chain complexities. Supply disruption can be defined in terms of facility capacities along all segments of the chain.

- Action 5-2c.-Synthesize energy resource commodity assessments (for example, coal, geothermal, natural gas, and oil) in support of domestic and global evaluations of the energy mix. Although the thrust of this effort could be forward looking, it could also establish an historical basis ("lessons-learned") for analysis, such as the age and decline rates of giant domestic fields from which a large proportion of oil is produced. The results from such a synthesis might also identify new fundamental research directions, and could be used to refine approaches to resource assessments.

- Action 5-2d.-Enhance mechanisms for prioritizing USGS energy and minerals research, assessments, and other science and information products to address identified data gaps and emerging needs. For example, a new genetic model may be needed for a previously unrecognized deposit type (goal 1) or geochemical research may be required to trace the cycling of an element with emerging uses (goal 2).

\section{Energy and Minerals Linkages Within the U.S. Geological Survey}

The USGS science strategy (U.S. Geological Survey, 2007) established a plan that recognized synergies among scientific expertise and capabilities within USGS and through partnerships, and the need for multidisciplinary approaches to address complex, multifaceted issues facing society. Coordination within USGS and with partners is important to fully understand the breadth and magnitude of interactions among energy and mineral lifecycles and air, land, soil, water, ecosystems services or functions, and human health from local, regional, national, and global perspectives.

The USGS energy and minerals science strategy mirrors the reality that complex societal issues demand diverse capabilities from every corner of the USGS and its partners. The science actions developed here represent key components of integrated studies at multiple scales. An evaluation of the energy and minerals mission area goals and actions (table 3) provides an initial identification of linkages within the USGS that could serve as opportunities for leveraging expertise and capabilities. For example, most of the actions under goals 1, 2 , and 4 reflect the need for enlisting expertise across mission areas. The converse is also true: efforts precipitated by the energy and minerals science strategy will contribute to other goals across the USGS. These linkages with USGS mission areas are dynamic and responsive to the particular blend of science a given issue demands, as noted in recent National Research Council studies (2009; 2012).

The actions in this science strategy also reflect the importance of early planning across USGS mission areas so that successful, timely integration of research activities can be established where appropriate. As one example, many aspects of USGS science are intrinsically global, and new opportunities for USGS international activities likely will arise in the next decade, underscoring the importance of foresight and planning so that the priorities of USGS, DOI, and the Nation are met (National Research Council, 2012).

Although not shown in this initial identification of common ground, an even broader range of linkages that include many partners, such as other DOI bureaus, Federal agencies, and State geological surveys, is acknowledged and anticipated. As one approach to leverage capabilities and expertise across agencies, the USGS operates under a number of memoranda of understanding (MOU) and interagency agreements. For example, the DOE, DOI (USGS), and EPA signed a memorandum of agreement in 2012 to enhance cooperation and facilitate the development of a focused, collaborative effort to address the highest priority research and development challenges associated with safely and prudently developing unconventional shale gas and tight oil resources to inform sound management and policy decisions by Federal, State, tribal, and local entities responsible for ensuring prudent development of energy resources and protecting human health and the environment (Department of Energy, Department of the Interior, and Environmental Protection Agency, 2012). When leveraged with expertise from other partners, the actions in this USGS Energy and Minerals Science Strategy can yield results providing a more comprehensive and integrated understanding of natural resources and facilitate the dissemination of science, information, and tools to a range of audiences, including scientists, cooperators, resource managers, policymakers, and the public. 
Table 3. U.S. Geological Survey energy and minerals science strategy actions and intersections with other mission areas.

[Gray-shaded rows denote actions for which the outcomes can be achieved largely through energy and minerals core expertise, capabilities, and network of partners. Red dots denote actions for which significant leveraging of expertise and capabilities from other mission areas and respective partners will be needed to fully achieve desired outcomes. USGS, U.S. Geological Survey; 3D, three-dimensional; DOI, U.S. Department of the Interior; EEZ, Exclusive Economic Zone; NMIC, National Minerals Information Center]

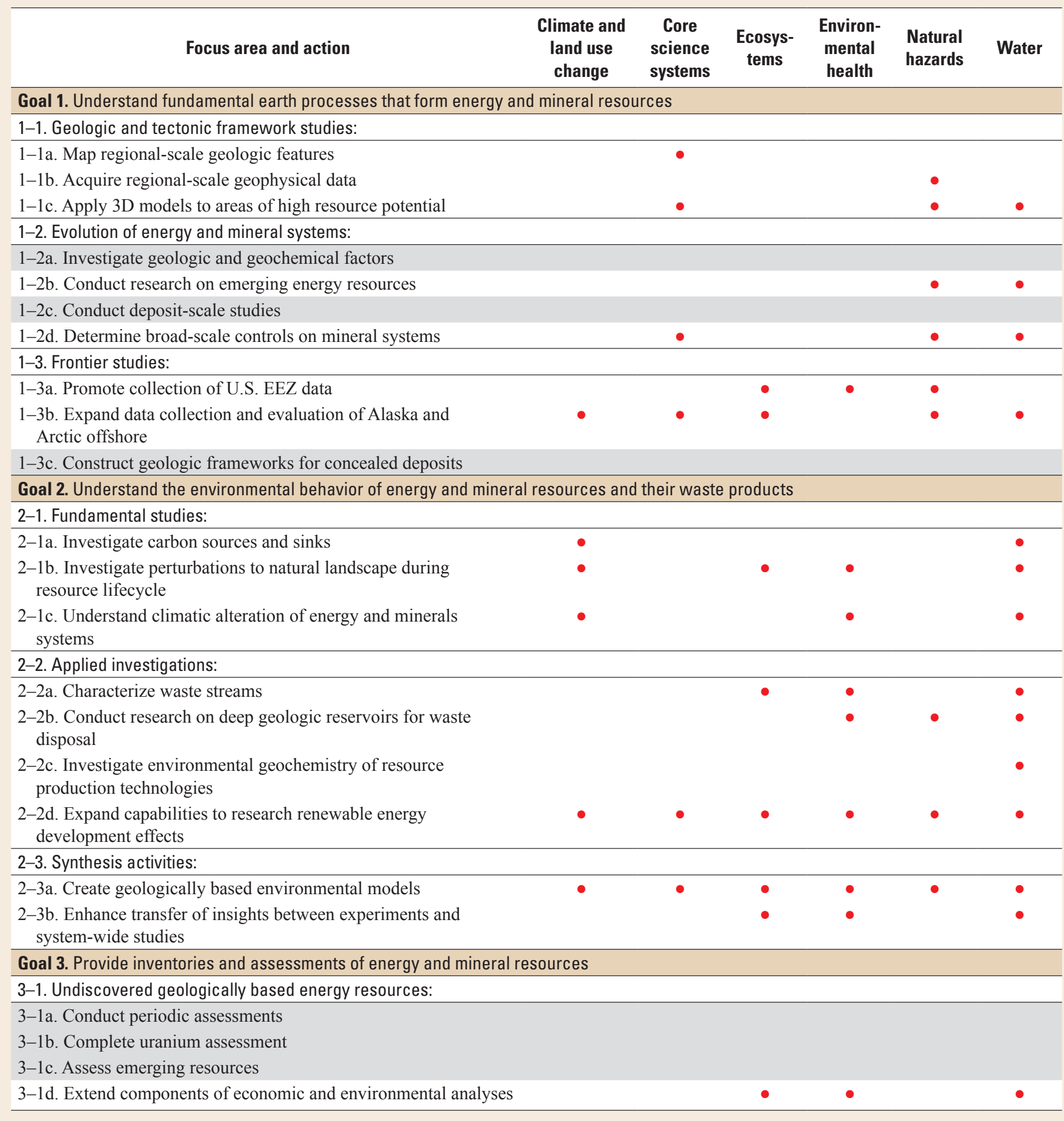


Table 3. U.S. Geological Survey energy and minerals science strategy actions and intersections with other mission areas.-Continued

[Gray-shaded rows denote actions for which the outcomes can be achieved largely through energy and minerals core expertise, capabilities, and network of partners. Red dots denote actions for which significant leveraging of expertise and capabilities from other mission areas and respective partners will be needed to fully achieve desired outcomes. USGS, U.S. Geological Survey; 3D, three-dimensional; DOI, U.S. Department of the Interior; EEZ, Exclusive Economic Zone; NMIC, National Minerals Information Center]

\begin{tabular}{|c|c|c|c|c|c|c|}
\hline Focus area and action & $\begin{array}{l}\text { Climate and } \\
\text { land use } \\
\text { change }\end{array}$ & $\begin{array}{c}\text { Core } \\
\text { science } \\
\text { systems }\end{array}$ & $\begin{array}{l}\text { Ecosys- } \\
\text { tems }\end{array}$ & $\begin{array}{l}\text { Environ- } \\
\text { mental } \\
\text { health }\end{array}$ & $\begin{array}{l}\text { Natural } \\
\text { hazards }\end{array}$ & Water \\
\hline \multicolumn{7}{|l|}{ 3-2. Discovered nonfuel mineral resources: } \\
\hline \multicolumn{7}{|l|}{ 3-2a. Expand partnerships } \\
\hline \multicolumn{7}{|l|}{ 3-2b. Establish a periodic review } \\
\hline \multicolumn{7}{|l|}{ 3-2c. Expand due-diligence field studies } \\
\hline \multicolumn{7}{|l|}{$\begin{array}{l}3-2 \mathrm{~d} \text {. Enhance scope and functionality of domestic discovered } \\
\text { resources database }\end{array}$} \\
\hline \multicolumn{7}{|l|}{ 3-2e. Strengthen and expand NMIC analytical capabilities } \\
\hline \multicolumn{7}{|l|}{ 3-3. Undiscovered nonfuel mineral resources: } \\
\hline \multicolumn{7}{|l|}{$\begin{array}{l}\text { 3-3a. Reevaluate methodologies for undiscovered mineral } \\
\text { resources assessments }\end{array}$} \\
\hline \multicolumn{7}{|c|}{ Goal 4. Understand the effects of energy and mineral development on natural resources and society } \\
\hline \multicolumn{7}{|l|}{$\begin{array}{l}\text { 4-1b. Provide information to large landscape conservation } \\
\text { initiatives }\end{array}$} \\
\hline 4-1c. Develop new nationwide spatial data products & & $\bullet$ & & & & \\
\hline \multicolumn{7}{|c|}{ 4-2. Explore interdisciplinary approaches for assessing effects of energy and mineral resources development: } \\
\hline 4-2a. Identify metrics or indicators & $\bullet$ & $\bullet$ & $\bullet$ & $\bullet$ & $\bullet$ & $\bullet$ \\
\hline 4-2b. Develop and refine methods for incorporating metrics & $\bullet$ & $\bullet$ & $\bullet$ & $\bullet$ & $\bullet$ & $\bullet$ \\
\hline $\begin{array}{l}\text { 4-2c. Develop methods to estimate potential land surface and } \\
\text { seabed disturbance }\end{array}$ & - & & $\bullet$ & $\bullet$ & $\bullet$ & $\bullet$ \\
\hline 4-2d. Assess effects of renewable energy development & • & • & • & - & • & $\bullet$ \\
\hline \multicolumn{7}{|l|}{ 5-2. Evolving issues affect long-term availability: } \\
\hline \multicolumn{7}{|l|}{$\begin{array}{l}\text { 5-2a. Develop approaches for identifying strategic and critical } \\
\text { mineral materials }\end{array}$} \\
\hline \multicolumn{7}{|l|}{$\begin{array}{l}\text { 5-2b. Conduct targeted studies on global flow of critical mineral } \\
\text { materials }\end{array}$} \\
\hline \multicolumn{7}{|l|}{ 5-2c. Synthesize energy resource commodity assessments } \\
\hline $\begin{array}{l}\text { 5-2d. Enhance mechanisms for prioritizing USGS energy and } \\
\text { minerals research }\end{array}$ & & & & & & \\
\hline
\end{tabular}




\section{References Cited}

Ahlbrandt, T.S., Charpentier, R.R., Klett, T.R., Schmoker, J.W., Schenk, C.J., and Ulmishek, G.F., 2005, Global resource estimates from total petroleum systems: American Association of Petroleum Geologists Memoir 86, 324 p.

Alaska National Interest Lands Conservation Act of 1980: U.S. Government Printing Office, Washington, D.C., accessed November 2, 2012, at http://www.gpo.gov/fdsys/ pkg/USCODE-2011-title16/pdf/USCODE-2011-title16chap51.pdf.

Alpine, A.E., ed., 2010, Hydrological, geological, and biological site characterization of breccia pipe uranium deposits in northern Arizona: U.S. Geological Survey Scientific Investigations Report 2010-5025, 353 p., 1 pl., scale 1:375,000. (Also available at $h t t p: / / p u b s . u s g s . g o v / s i r / 2010 / 5025 /$.

American Physical Society Panel on Public Affairs and the Materials Research Society, 2011, Energy critical elements: Securing materials for emerging technologies: 28 p. (Also available at: http://www.aps.org/policy/ reports/popa-reports/loader.cfm?csModule=security/ getfile\&PageID=236337.)

Attanasi, E.D., and Freeman, P.A., 2011, Survey of stranded gas and delivered costs to Europe of selected gas resources: SPE Economics and Management, v. 3, no. 3, p.149-162.

Biewick, L.R.H., 2008, Areas of historical oil and gas exploration and production in the United States: U.S. Geological Survey Digital Data Series 69-Q. (Also available at $h t t p: / /$ pubs.usgs.gov/dds/dds-069/dds-069-q/.)

Brown, W.M., III, Matos, G.R., and Sullivan, D.E., (comps.), 2000, Materials and energy flows in the Earth science century - A summary of a workshop held by the USGS in November 1998: U.S. Geological Survey Circular 1194, 76 p. (Also available at: http://pubs.usgs.gov/circ/2000/ c1194/.)

Clark, R.N., Swayze, G.A., Hoefen, T.M., Green, R.O., Livo, K.E., Meeker, G.P., Sutley, S.J., Plumlee, G.S., Pavri, B., Sarture, C., Boardman, J., Brownfield, I.K., and Morath, L.C., 2006, Environmental mapping of the World Trade Center area with imaging spectroscopy after the September 11, 2001 attack, chap. 4 of Gaffney, J.S., and Marley, N.A., eds., Urban aerosols and their impacts-Lessons learned from the World Trade Center tragedy: American Chemical Society Symposium Series, v. 919, p. 66-83.

Coleman, J.L., Milici, R.C., Cook, T.A., Charpentier, R.R., Kirschbaum, M., Klett, T.R., Pollastro, R.M., and Schenk, C.J., 2011, Assessment of undiscovered oil and gas resources of the Devonian Marcellus Shale of the Appalachian Basin Province, 2011: U.S. Geological Survey Fact Sheet 2011-3092, 2 p. (Also available at http://pubs.usgs. gov/fs/2011/3092/.)
Deep Seabed Hard Mineral Resources Act of 1980: U.S. Government Printing Office, Washington, D.C., accessed November 2, 2012, at http://www.gpo.gov/fdsys/pkg/ USCODE-2011-title30/pdf/USCODE-2011-title30-chap26. $p d f$.

Department of Energy, Department of the Interior, and Environmental Protection Agency, 2012, Multi-agency collaboration on unconventional oil and gas research: Memorandum of Agreement, 7 p., accessed November 2, 2012, at $h t t p: / / w w w . u n c o n v e n t i o n a l . e n e r g y . g o v / p d f / o i l \_a n d \_g a s$ research_mou.pdf.

duBray, E.A., (ed.), 1995, Preliminary compilation of descriptive geoenvironmental mineral deposit models: U.S. Geological Survey Open-File Report 95-831, 272 p. (Also available at: $h t t p: / / p u b s . u s g s . g o v / o f / 1995 / o f r-95-0831 /$.

Energy Independence and Security Act of 2007: U.S. Government Printing Office, Washington, D.C., 311 p., accessed November 2, 2012, at http://www.gpo.gov/fdsys/pkg/PLAW110publ140/pdf/PLAW-110publ140.pdf.

Energy Policy Act of 1992: The Library of Congress, Washington, D.C., accessed November 2, 2012, at http://thomas. loc.gov/cgi-bin/bdquery/z?d102:H.R.776: .

Energy Policy Act of 2005: U.S. Government Printing Office, Washington, D.C., 551 p., accessed November 2, 2012, at http://www.gpo.gov/fdsys/pkg/PLAW-109publ58/pdf/PLAW109publ58.pdf.

Energy Policy and Conservation Act Amendments of 2000: in Energy Act of 2000, U.S. Government Printing Office, Washington, D.C., 26 p., accessed November 2, 2012, at $h t t p: / / w w w . g p o . g o v / f d s y s / p k g / P L A W-106 p u b l 469 / p d f /$ PLAW-106publ469.pdf.

Eppinger, R.G., 2002, Pre-fire baseline stream-sediment and stream-water geochemical data from a recently burned area in central Idaho, and suggestions for application of geochemical data to wildfire science, in Coffelt, J.L., and Livingston, R.K., 2002, Second U.S. Geological Survey Wildland Fire Workshop; Los Alamos, New Mexico; October 31-November 3, 2000: U.S. Geological Survey OpenFile Report 2002-11, p. 51. (Also available at $h t t p: / / p u b s$. usgs.gov/of/2002/0011/report.pdf.)

Eppinger, R.G., Briggs, P.H., Rieffenberger, B., Van Dorn, C., Brown, Z.A., Crock, J.G., Hageman, P.H., Meier, A., Sutley, S.J., Theodorakos, P.M., and Wilson, S.A., 2003, Geochemical data for stream sediment and surface water samples from Panther Creek, the middle fork of the Salmon River, and the main Salmon River, collected before and after the Clear Creek, Little Pistol, and Shellrock wildfires of 2000 in central Idaho: U.S. Geological Survey Open-File Report 2003-152, 32 p. (Also available at http://pubs.usgs. gov/of/2003/152/.) 
Executive Order 12656, 1988, Assignment of emergency preparedness responsibilities: Federal Register, v. 53, p. 47,491, accessed November 1, 2012, at $h t t p: / / w w w$. archives.gov/federal-register/codification/executiveorder/12656.html.

Executive Order 13603, 2012, National defense resources preparedness: Federal Register, v. 77, no. 56, p. 16651-16660, accessed November 1, 2012, at http://www.gpo.gov/fdsys/ pkg/FR-2012-03-22/pdf/2012-7019.pdf.

Executive Order 13605, 2012, Supporting safe and responsible development of unconventional domestic natural gas resources: Federal Register, v. 77, no. 74, p. 23107-23108, accessed November 1, 2012, at http://www.gpo.gov/fdsys/ pkg/FR-2012-04-17/pdf/2012-9473.pdf.

Federal Coal Leasing Amendments Act, 1976: The Library of Congress, Washington, D.C., accessed November 2, 2012, at http://thomas.loc.gov/cgi-bin/bdquery/ z?d094:SN00391:@@L\&summ2=m\&|TOM:/bss/ d094query.htmll.

Federal Land Policy and Management Act of 1976: U.S. Government Printing Office, Washington, D.C., accessed November 2, 2012, at http://www.gpo.gov/fdsys/pkg/ USCODE-2011-title43/pdf/USCODE-2011-title43-chap35. $p d f$.

Forest and Rangeland Renewable Resources Planning Act of 1974: U.S. Government Printing Office, Washington, D.C., accessed November 2, 2012, at http://www.gpo.gov/fdsys/ pkg/USCODE-2011-title16/pdf/USCODE-2011-title16chap36.pdf.

Geothermal Energy Research, Development, and Demonstration Act, 1974: U.S. Government Printing Office, Washington, D.C., accessed November 2, 2012, at http://www.gpo. gov/fdsys/pkg/USCODE-2011-title30/pdf/USCODE-2011title30-chap24.pdf.

Geothermal Steam Act Amendments of 1988: The Library of Congress, Washington, D.C., accessed November 2, 2012, at http://thomas.loc.gov/cgi-bin/bdquery/ z?d100:SN01889:@@D\&summ2=0\&.

Gundersen, L.C.S., Belnap, J., Goldhaber, M., Goldstein, A., Haeussler, P.J., Ingebritsen, S.E., Jones, J.W., Plumlee, G.S., Thieler, E.R., Thompson, R.S., and Back, J.M., 2011, Geology for a changing world 2010-2020-Implementing the U.S. Geological Survey science strategy: U.S. Geological Survey Circular 1369, 68 p. (Also available at http://pubs. usgs.gov/circ/circ1369/.)
Hein, J.R., McIntyre, B.R., and Piper, D.Z., 2005, Marine mineral resources of Pacific Islands-A review of the Exclusive Economic Zones of islands of U.S. affiliation, excluding the State of Hawaii: U.S. Geological Survey Circular 1286, 69 p. (Also available at: http://pubs.er.usgs.gov/publication/ cir1286.)

Higley, D.K., 2011, Undiscovered petroleum resources for the Woodford Shale and Thirteen Finger Limestone-Atoka Shale assessment units, Anadarko Basin: U.S. Geological Survey Open-File Report 2011-1242, 3 sheets. (Also available at $h t t p: / / p u b s . u s g s . g o v / o f / 2011 / 1242 /$.

Intergovernmental Panel on Climate Change, 2011, Special Report on Renewable Energy Sources and Climate Change Mitigation: Edenhofer, O., Pichs-Madruga, R., Sokona, Y., Seyboth, K., Matschoss, P., Kadner, S., Zwickel, T., Eickemeier, P., Hansen, G., Schlömer, S., and von Stechow, C., eds., Working Group III of the Intergovernmental Panel on Climate Change: Cambridge University Press, Cambridge, United Kingdom and New York, NY, USA, 1,075 p.

Jacobsen, L.J., Glynn, P.D., Phelps, G.A., Orndorff, R.C., Bawden, G.W., and Grauch, V.J.S., 2011, U.S. Geological Survey-A synopsis of three-dimensional modeling, chap. 13 of Berg, R.C., Mathers, S.J., Kessler, Holger, and Keefer, D.A., eds., Synopsis of current three-dimensional mapping and modeling in geological survey organizations: Illinois State Geological Survey Circular 578, p. 69-79.

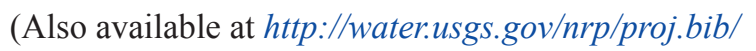
Publications/2011/jacobsen_glynn_etal_2011.pdf.)

Jones, L.M., Bernknopf, R., Cox, D., Goltz, J., Hudnut, K., Mileti, D., Perry, S., Ponti, D., Porter, K., Reichle, M., Seligson, H., Shoaf, K., Treiman, J., and Wein, A., 2008, The ShakeOut scenario: U.S. Geological Survey OpenFile Report 2008-1150 and California Geological Survey Preliminary Report 25, 312 p. (Also available at http://pubs. usgs.gov/of/2008/1150/.)

Kostick, D.S., 1996, The material flow concept for materials: Nonrenewable Resources, v. 5, no. 4, p. 211-233.

Labson, V.F., Clark, R.N., Swayze, G.A., Hoefen, T.M., Kokaly, R., Livo, K.E., Powers, M.H., Plumlee, G.S., and Meeker, G.P., 2010, Estimated minimum discharge rates of the Deepwater Horizon spill-Interim report to the Flow Rate Technical Group from the Mass Balance Team: U.S. Geological Survey Open-File Report 2010-1132, 4 p. (Also available at $h t t p: / / p u b s . u s g s . g o v / o f / 2010 / 1132 /$.)

Langer, W.H., 2011, The ShakeOut scenario-Meeting the needs for construction aggregates, asphalt, and concrete: Earthquake Spectra, v. 27, p. 505-520. 
Menzie, W.D., Baker, M.S., Bleiwas, D.I., and Kuo, C., 2011, Mines and mineral processing facilities in the vicinity of the March 11, 2011, earthquake in northern Honshu, Japan: U.S. Geological Survey Open-File Report 2011-1069, 7 p. (Also available at $h t t p: / / p u b s . u s g s . g o v / o f / 2011 / 1069 /$.)

Mercier, T.J., and Johnson, R.C., 2012, Isopach and isoresource maps for oil shale deposits in the Eocene Green River Formation for the combined Uinta and Piceance Basins, Utah and Colorado: U.S. Geological Survey Scientific Investigations Report 2012-5076, 85 p., 1 pl. (Also available from: http://pubs.usgs.gov/sir/2012/5076/.)

Methane Hydrate Research and Development Act of 2000: U.S. Government Printing Office, Washington, D.C., 6 p., accessed November 2, 2012, at http://www.gpo.gov/fdsys/ pkg/PLAW-106publ193/pdf/PLAW-106publ193.pdf.

Milici, R.C., Coleman, J.L., Rowan, E.L., Cook, T.A., Charpentier, R.R., Kirschbaum, M.A., Klett, T.R., Pollastro, R.M., and Schenk, C.J., 2012, Assessment of undiscovered oil and gas resources of the East Coast Mesozoic basins of the Piedmont, Blue Ridge Thrust Belt, Atlantic Coastal Plain, and New England Provinces, 2011: U.S. Geological Survey Fact Sheet 2012-3075, 2 p. (Also available at: http://pubs.usgs.gov/fs/2012/3075/.)

Mining and Minerals Policy Act of 1970: U.S. Government Printing Office, Washington, D.C., accessed November 2, 2012, at http://www.gpo.gov/fdsys/pkg/USCODE-2011title30/pdf/USCODE-2011-title30-chap2-sec21a.pdf.

National Academy of Sciences, 1913, A history of the first half-century of the National Academy of Sciences, 1863-1913: Washington, D.C., The Lord Baltimore Press, $427 \mathrm{p}$.

National Environmental Policy Act of 1969: U.S. Government Printing Office, Washington, D.C., accessed November 2, 2012, at http://www.gpo.gov/fdsys/pkg/USCODE-2011title42/pdf/USCODE-2011-title42-chap55.pdf.

National Materials and Minerals Policy, Research, and Development Act of 1980: U.S. Government Printing Office, Washington, D.C., accessed November 2, 2012, at http://www.gpo.gov/fdsys/pkg/USCODE-2011-title30/pdf/ USCODE-2011-title30-chap28.pdf.

National Research Council, 1996, Mineral resources and sustainability - Challenges for earth scientists: Washington, D.C., The National Academies Press, 26 p.

National Research Council, 2004, Materials count-The case for materials flow analysis: Washington, D.C., The National Academies Press, 144 p.
National Research Council, 2005, Valuing ecosystem services: toward better environmental decision making: Washington, D.C., The National Academies Press, 290 p.

National Research Council, 2007, Earth materials and health: Research priorities for Earth science and public health: Washington, D.C., The National Academies Press, 188 p.

National Research Council, 2008, Minerals, critical minerals, and the U.S. economy: Washington, D.C., The National Academies Press, 264 p.

National Research Council, 2009, Toward a sustainable and secure water future: A leadership role for the U.S. Geological Survey: Washington, D.C., The National Academies Press, $128 \mathrm{p}$.

National Research Council, 2012, International science in the national interest at the U.S. Geological Survey: Washington, D.C., The National Academies Press, 112 p.

Nuclear Waste Policy Act of 1982, accessed November 2, 2012, at http://epw.senate.gov/nwpa82.pdf.

Organic Act of 1879: U.S Government Printing Office, Washington, D.C., accessed November 2, 2012, at http://www. gpo.gov/fdsys/pkg/USCODE-2011-title43/pdf/USCODE2011-title43-chap2.pdf.

Plumlee, G.S., and Ziegler, T.L., 2003, The medical geochemistry of dusts, soils, and other earth materials, in Lollar, B.S., ed., Environmental geochemistry: Treatise on Geochemistry, v. 9, p. 1-61. (Also available at $h t t p: / / w w w$. sciencedirect.com/science/article/pii/B0080437516090502.)

Plumlee, G.S., Meeker, G.P., Lovelace, J.K., Rosenbauer, R.J., Lamonthe, P.J., Furlong, E.T., and Demas, C.R., 2006, USGS environmental characterization of flood sediments left in the New Orleans area after Hurricanes Katrina and Rita, 2005-Progress report: U.S. Geological Survey OpenFile Report 2006-1023, 74 p. (Also available at $h t t p: / / p u b s$. usgs.gov/of/2006/1023/.)

President's Council of Advisors on Science and Technology, 2011, Sustaining environmental capital: protecting society and the economy: Report to the President, Washington, D.C., 145 p.

Scott, D.C., Haacke, J.E., Osmonson, L.M., Luppens, J.A., Pierce, P.E., and Rohrbacher, T.J., 2011, Assessment of coal geology, resources, and reserves in the northern Wyoming Powder River Basin: U.S. Geological Survey Open-File Report 2010-1294, 136 p. (Also available at http://pubs. usgs.gov/of/2010/1294/. 
Strategic and Critical Materials Stock Piling Act of 1946: U.S. Government Printing Office, Washington, D.C., accessed November 5, 2012, at http://www.gpo.gov/fdsys/pkg/ USCODE-2011-title50/pdf/USCODE-2011-title50-chap5subchapIII.pdf.

The Balanced Budget Downpayment Act, I, 1996: U.S. Government Printing Office, Washington, D.C., 23 p., accessed November 2, 2012, at http://www.gpo.gov/fdsys/pkg/PLAW104publ99/pdf/PLAW-104publ99.pdf.

Transfer of functions from Secretary of Interior to Secretary of Agriculture, 1960: U.S. Government Printing Office, Washington, D.C., accessed on November 2, 2012, at $h t t p: / / w w w$. gpo.gov/fdsys/pkg/USCODE-2011-title7/pdf/USCODE2011-title7-chap55-sec2201.pdf.

United Nations, 1982, United Nations convention on the law of the sea: Montego Bay, Jamaica, United Nations, 202 p., accessed April 12, 2012, at http://www.un.org/Depts/los/ convention_agreements/convention_overview_convention. htm.

United Nations World Commission on Environment and Development, 1987, Our common future: United Nations, 374 p. (Also available at http://worldinbalance.net/ intagreements/1987-brundtland.php.)

U.S. Commission on Ocean Policy, 2004, An ocean blueprint for the 21st century-Final report: Washington, D.C., U.S. Commission on Ocean Policy, 438 p. plus appendixes. (Also available at $h t t p: / / w w w . o c e a n c o m m i s s i o n . g o v / d o c u m e n t s /$ full_color_rpt/000_ocean_full_report.pdf.)

U.S. Energy Information Administration, 2012, Annual energy review 2011: U.S. Energy Information Administration DOE/

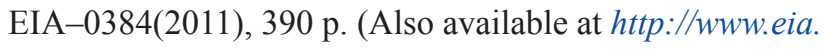
gov/totalenergy/data/annual/pdf/aer.pdf.)

U.S. Geological Survey, 2007, Facing tomorrow's challenges-U.S. Geological Survey science in the decade 2007-2017: U.S. Geological Survey Circular 1309, 67 p. (Also available at $h t t p: / / p u b s . u s g s . g o v / c i r c / 2007 / 1309 /$.

U.S. Geological Survey Bighorn Basin Assessment Team, 2010, Petroleum systems and geologic assessment of oil and gas in the Bighorn Basin Province, Wyoming and Montana: U.S. Geological Survey Digital Data Series 69-V. (Also available at $h t t p: / / p u b s . u s g s . g o v / d d s / d d s-069 / d d s-069-v /$.

U.S. Geological Survey Oil Shale Assessment Team, 2010a, Oil shale and nahcolite resources of the Piceance Basin, Colorado: U.S. Geological Survey Digital Data Series 69-Y. (Also available at $h t t p: / / p u b s . u s g s . g o v / d d s / d d s-069 / d d s-$ $069-y /$.
U.S. Geological Survey Oil Shale Assessment Team, 2010b, Oil shale resources of the Uinta Basin, Utah and Colorado: U.S. Geological Survey Digital Data Series 69-BB. (Also available at $h t t p: / / p u b s . u s g s . g o v / d d s / d d s-069 / d d s-069-b b /$.

U.S. Geological Survey, 2012, Mineral commodity summaries 2012: U.S. Geological Survey, 201 p. (Also available at http://minerals.usgs.gov/minerals/pubs/mcs/2012/mcs2012. $p d f$.)

Van Gosen, B.S., Gillerman, V.S., and Armbrustmacher, T.J., 2009, Thorium deposits of the United States-Energy resources for the future?: U.S. Geological Survey Circular 1336, 21 p. (Also available at http://pubs.usgs.gov/ circ/1336/.)

Wilderness Act of 1964: U.S. Government Printing Office, Washington, D.C., accessed November 2, 2012, at http:// www.gpo.gov/fdsys/pkg/USCODE-2011-title16/pdf/ USCODE-2011-title16-chap23.pdf.

Williams, B.K., Szaro, R.C., and Shapiro, C.D., 2009, Adaptive management-The U.S. Department of the Interior technical guide: U.S. Department of the Interior, 72 p. (Also available at $h t t p: / / w w w . d o i . g o v / i n i t i a t i v e s /$ AdaptiveManagement/TechGuide.pdf.)

Wolf, R.E., Hoefen, T.M., Hageman, P.L., Morman, S.A., and Plumlee, G.S., 2010, Speciation of arsenic, selenium, and chromium in wildfire impacted soils and ashes: U.S. Geological Survey Open-File Report 2010-1242, 29 p. (Also available at http://pubs.usgs.gov/of/2010/1242/.)

Wyoming Landscape Conservation Initiative, [undated], Integrated assessment: Wyoming Landscape Conservation Initiative, accessed April 6, 2012, at http://www.wlci.gov/. 


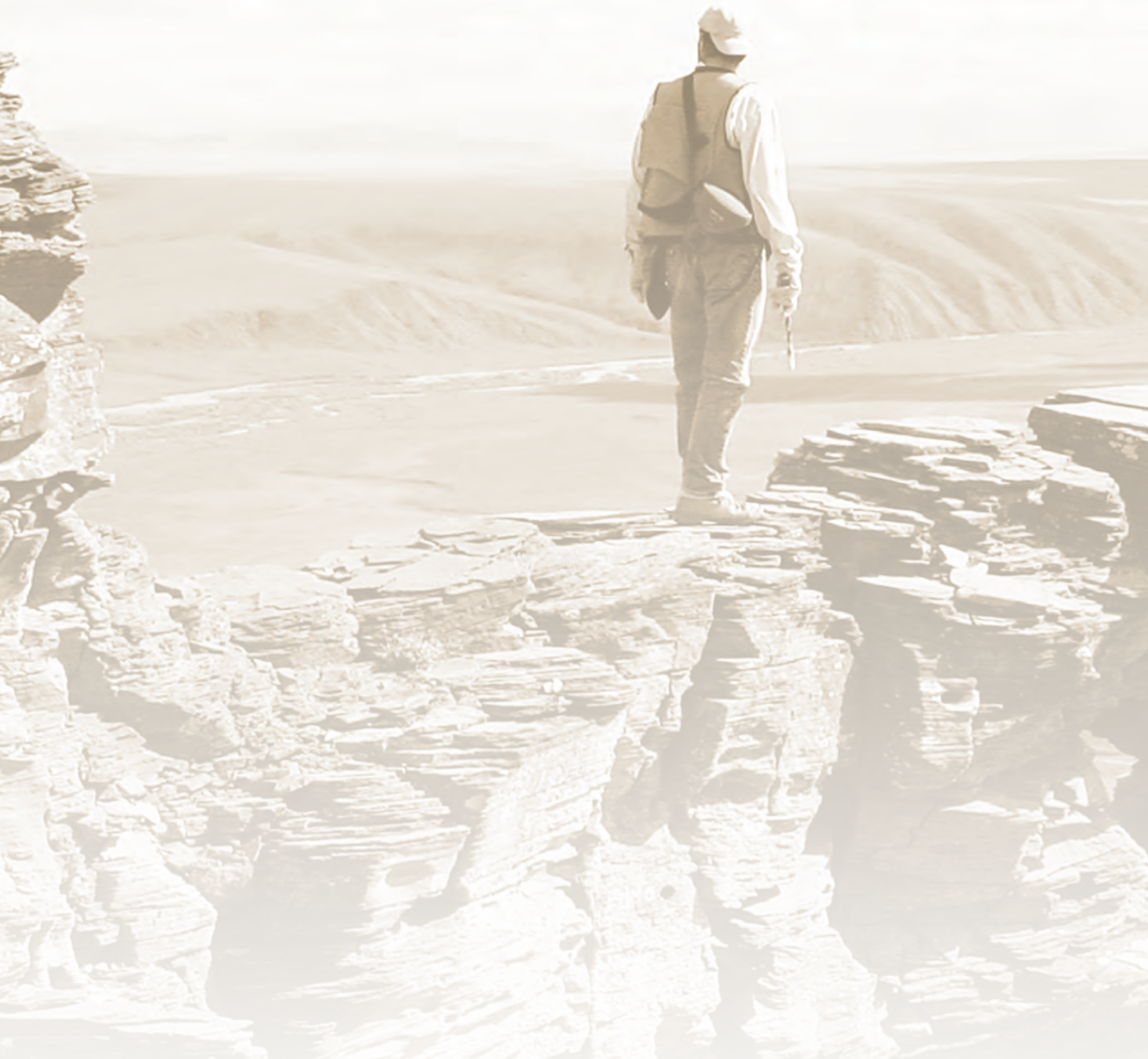


